\title{
Is Patent Law TeChNology-SPecific?
}

\author{
By Dan L. Burk' and Mark A. Lemley ${ }^{\ddagger}$
}

\section{TABLE OF CONTENTS}

I. HETEROGENEITY IN THE PATENT LAW ........................................................... 1158

A. The History of the Uniform Patent System ................................................. 1158

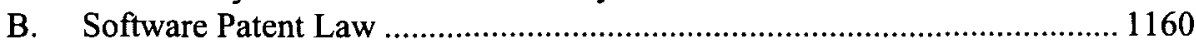

C. Biotechnology Patent Cases ........................................................................ 1173

D. The Divergent Standards .............................................................................. 1183

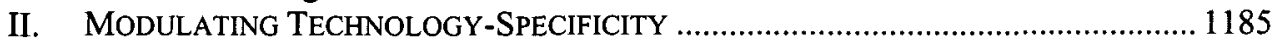

A. The Role of the PHOSITA …………………………............................ 1185

B. Misapplication of the PHOSITA Standard................................................... 1190

C. Obstacles to Applying the PHOSITA Standard Properly .............................. 1196

III. FIXING THE PHOSITA DOCTRINE ………………………….............................. 1202

[The software patent cases] stand as a testament to the ability of law to adapt to new and innovative concepts, while remaining true to basic principles. ${ }^{1}$

Fundamental shifts in technology and in the economic landscape are rapidly making the current system of intellectual property rights unworkable and ineffective. Designed more than 100 years ago to meet the simpler needs of an industrial era, it is an undifferentiated, one-size-fits-all system. Although treating all advances in knowledge in the same way may have worked when most patents were granted for new mechanical devices, today's brainpower industries pose challenges that are far more complex. $^{2}$

(C) 2002 Dan L. Burk \& Mark A. Lemley

$\dagger$ Oppenheimer, Wolff, \& Donnelly Professor of Law, University of Minnesota.

$\ddagger$ Professor of Law, Boalt Hall School of Law, University of California, Berkeley; of counsel, Keker \& Van Nest LLP.

We thank Rochelle Dreyfuss, Rebecca Eisenberg, Richard Epstein, Dan Farber, Nancy Gallini, Wendy Gordon, Rose Hagan, Bruce Hayden, David Hyman, Brian Kahin, Clarisa Long, David McGowan, Craig Nard, Arti Rai, Polk Wagner, Tarra Zynda, and participants at the Telecommunications Policy Research Conference, the Washington University Conference on the Human Genome, the University of Toronto conference on Competition and Innovation, and a faculty workshop at the University of Minnesota Law School for comments on an earlier draft of this or a related paper; Kristen Dahling and Colleen Chien for research assistance, and the University of Minnesota Law School, Boalt Hall School of Law, University of California, Berkeley and a generous grant from Washington University for research funding.

1. AT\&T v. Excel Communications, 172 F.3d 1352, 1356 (Fed. Cir. 1999).

2. Lester Thurow, Needed: A New System of Intellectual Property Rights, HARV. Bus. Rev., Sept.-Oct. 1995, at 95, 95. 
Patent law has a general set of legal rules to govern the validity and infringement of patents in a wide variety of technologies. With very few exceptions, the statute does not distinguish between different technologies in setting and applying legal standards. ${ }^{3}$ Rather, those standards are designed to adapt flexibly to new technologies, encompassing "anything under the sun made by man." In theory, then, we have a unified patent system that provides technology-neutral protection to all kinds of technologies.

Of late, however, we have noticed an increasing divergence between the rules themselves and the application of the rules to different industries. The best examples are biotechnology and computer software. In biotechnology cases, the Federal Circuit has bent over backwards to find biotechnological inventions nonobvious, even if the prior art demonstrates a clear plan for producing the invention. On the other hand, the court has imposed stringent enablement and written description requirements on biotechnology patents that do not show up in other disciplines. In computer software cases, the situation is reversed. The Federal Circuit has essentially excused software inventions from compliance with the enablement and best mode requirements, but has done so in a way that raises serious questions about how stringently it will read the nonobviousness requirements. As a practical matter, it appears that while patent law is technology-neutral in theory, it is technology-specific in application. We provide evidence for this claim in Part I. While our analysis focuses on biotechnology and computer software, which present two extreme examples of this phenomenon, our approach may have application to other industries as well, notably smallmolecule chemistry.

Part II explains how the application of the same general legal standards can lead to such different results in diverse industries. Much of the variance in patent standards is attributable to the use of a legal construct, the "person having ordinary skill in the art" (PHOSITA), to determine obviousness and enablement. The more skill those in the art have, the less information an applicant has to disclose in order to meet the enablement requirement-but the harder it is to meet the nonobviousness requirement. The level of skill in the art affects not just patent validity, but also patent scope. Because both claim construction and the doctrine of equivalents turn on the understanding of the PHOSITA in certain circumstances, judgments the court makes about ordinary skill in an industry affect the scope of patents that issue.

3. See, e.g., 35 U.S.C. $\S 103$ (b) (2000) (creating a special obviousness provision for biotechnology).

4. Diamond v. Chakrabarty, 447 U.S. 303, 309 (1980) (citing S. REP. No. 1979, at 5 (1952); H.R. REP. No. 1923, at 6 (1952)). 
One reading of the biotechnology and computer software cases is that the Federal Circuit believes computer programmers are extremely skilled, while biotechnology experts know very little about their art. This implication is closely tied to the Federal Circuit's designation of some technologies as belonging to the "unpredictable arts"; the court treats biotechnology as if the results obtained in that art are somehow outside the control of those of skill in the art, whereas computer science is treated as if those of skill in the art have their outcomes well in hand.

We do not challenge the idea that the standards in each industry should vary with the level of skill in that industry. We think the use of the PHOSITA provides needed flexibility for patent law, permitting it to adapt to new technologies without losing its essential character. We fear, however, that the Federal Circuit has not applied that standard properly in either the biotechnology or computer software fields. The court has a perception of both fields that was set in earlier cases but which does not reflect the modern realities of either industry. The changes in an industry over time present significant structural problems for patent law, both because law is necessarily backward-looking and precedent-bound, and because applying different standards to similar inventions raises concerns about horizontal equity. Nonetheless, we believe the courts must take more care than they currently do to ensure that their assessments of patent validity are rooted in understandings of the technology that were accurate at the time the invention was made.

In Part III, we offer some suggestions for how to free the PHOSITA from its conceptual shackles in order to ensure that where patent law is technology-specific - as it inevitably will be-it is for the right reasons. The question of whether patent law is industry-specific is closely related to arguments over whether patent law should vary from industry to industry in any systematic way. This is a difficult policy question, and one we do not address in this Article, though we do so elsewhere. ${ }^{5}$ Here, we simply recognize that our nominally unitary patent system in fact conceals a wide variety of different legal rules, and suggest doctrinal changes to optimize certain rules for particular industries. In doing so, we hope to lay the groundwork for a broader exposition as to how patent policy may be tailored to provide optimal incentives for innovation.

5. See, e.g., Dan L. Burk \& Mark A. Lemley, Policy Levers in Patent Law (2002) (unpublished manuscript, on file with authors). 


\section{HETEROGENEITY IN THE PATENT LAW}

Intellectual property law generally aims to solve the "public goods" problem that arises in regard to creative activity. Legal rights in the product of creative activity allow creators to control and profit from goods that are costly to produce but which are virtually costless to reproduce or to appropriate once they have been created. A variety of intellectual property systems have been promulgated to deal with this problem for different, if occasionally overlapping, areas of subject matter. These various types of legal protection carry different scopes and lengths of protection, hopefully roughly appropriate to their subject areas. Copyright is generally addressed to artistic or aesthetic works, although it now includes software in its ambit; patent law generally addresses industrial or technological inventions; trade secrecy covers a wide range of valuable business assets. Each of these modes of protection covers a wide swath of subject matter; specialized statutes, sometimes called "sui generis" laws, are relatively rare. ${ }^{6}$ As a practical matter, Congress cannot enact a new form of intellectual property statute each time a new technology arises. ${ }^{7}$ Nevertheless, there are drawbacks to encompassing many types of subject matter within one broad system, as demonstrated by patent law.

\section{A. The History of the Uniform Patent System}

A patent statute was one of the first laws Congress passed, in 1790. Since that time, a patent statute has been a constant feature of the U.S. le-

6. At various times commentators have called for sui generis protection of specific subject matter. See, e.g., Peter S. Menell, Tailoring Legal Protection for Computer Software, 39 STAN. L. REV. 1329, 1364-65 (1987) (computer software); Pamela Samuelson, Creating a New Kind of Intellectual Property: Applying the Lessons of the Chip Law to Computer Programs, 70 MINN. L. REV. 471 (1985) (same); Dan L. Burk, Copyrightability of Recombinant DNA Sequences, 29 JURIMETRICS J. 469, 530-31 (1989) (biotechnology); Kenneth D. Crews, Looking Ahead and Shaping the Future: Provoking Change in Copyright Law, 49 J. COPYRIGHT SOC'Y USA 549, 564 (2001) (““One-size-fits-all' ultimately fits few."). Cf. Nancy Gallini \& Suzanne Scotchmer, Intellectual Property: When Is It the Best Incentive System?, in INNOVATION POLICY AND THE ECONOMY 2 51, 53 (Adam B. Jaffe et al. eds., 2001) ("[I]ntellectual property regimes should be designed so that the subject matter of each one has relatively homogenous needs for protection."). The Semiconductor Chip Protection Act of 1984 is one of the few examples where Congress heeded such encouragement. It created a unique form of intellectual property in the "mask works" embodying semiconductor chip circuit designs. See Semiconductor Chip Protection Act of 1984, 17 U.S.C. $\$ \S 901-914$ (2000).

7. See Louis Kaplow, The Patent-Antitrust Intersection: A Reappraisal, 97 HARV. L. REV. 1813, 1819-20 (1984); Richard Stern, The Bundle of Rights Suited to New Technology, 47 U. PITT. L. REV. 1229, 1261 (1986). 
gal landscape. ${ }^{8}$ While the nature of the patent system went through some rather dramatic changes in the first fifty years of the Republic-beginning with a requirement that two cabinet officials must personally review and sign off on any patent ${ }^{9}$ and swinging to the other extreme with an automatic registration system subject to caveats ${ }^{10}$-by 1836 the essential features of modern patent law were in place. ${ }^{11}$ Despite periodic revisions, most recently in 1952, the basic structure of the patent system has remained unchanged for 165 years.

Technology, of course, has changed dramatically during that time. The "useful arts" envisioned by the Framers were mechanical inventions useful in a primarily agrarian economy. Since that time, the country has gone through several periods of dramatic innovation in a wide variety of fields. As late as 1950, though, most inventions were still mechanical in nature. It is only in the last half-century-and to a large extent in the last twentyfive years, as Allison and Lemley show ${ }^{12}$ - that patent law has lost its primarily mechanical character, branching out into biotechnology, semiconductors, computer hardware and software, electronics, and telecommunications.

What is notable about this history is that the fundamental rules of patent law were set in a world in which inventions were mechanical. Because inventions in the past were far more homogenous than they are today, ${ }^{13}$ it made sense to have a unified set of rules for dealing with those inventions. The application of those old rules to new technologies has not been free

8. See, e.g., Bruce Bugbee, The Genesis of American Patent and Copyright LAW 126, 143 (1967); Edward C. Walterscheid, To Promote the Progress of Useful Arts: American Patent Law and Administration, 1787-1836, pt. 1, 79 J. PAT. \& TRADEMARK OfF. SOC'Y 61 (1997); Edward C. Walterscheid, To Promote the Progress of Useful Arts: American Patent Law and Administration, 1787-1836, pt. 2, 80 J. PAT. \& TRADEMARK OFF. SOC'Y 11 (1998). Even before that time, the U.S. colonies granted patent rights. See ROBERT P. MERGES ET AL., INTELlectual PROPERTY IN THE NEW TECHNOLOGICAL AgE 127,128 (2d ed. 2000).

9. This was a feature of the short-lived Patent Act of 1790. See Walterscheid, supra note 8; Edward C. Walterscheid, Charting a Novel Course: The Creation of the Patent Act of 1790, 25 AIPLA Q.J. 445, 519-20 (1997).

10. The 1793 Act replaced the cumbersome cabinet-level review with a registration system. Under this system, patents were granted without examination unless a competitor or other interested party filed a "caveat"- essentially a request to be notified and given a chance to object if someone patented in a particular field. See Walterscheid, supra note 8 , at 73 .

11. See MERGES ET AL., supra note 8, at 128.

12. See John R. Allison \& Mark A. Lemley, The Growing Complexity of the United States Patent System, 82 B.U. L. REV. 77, 87-90 (2002).

13. Id. at 79-80. 
from controversy. Some have suggested that the unified rules suitable for the old, homogeneous world are no longer appropriate in today's increasingly complex innovative landscape. ${ }^{14}$ But without changing the rules themselves, in the last dozen years the Federal Circuit has applied those rules in a way that effectively creates different standards for different industries. ${ }^{15}$ In the sections that follow, we examine the treatment of two such industries in detail: computer software and biotechnology.

\section{B. Software Patent Law}

Software is patentable today, though it was not always so. ${ }^{16}$ The Federal Circuit moved towards declaring software patentable by fits and starts for years. Finally, with the late-1990s decisions in State Street Bank ${ }^{17}$ and $A T \& T$ v. Excel, ${ }^{18}$ the court unreservedly admitted software to the pantheon

14. See infra notes 120-124 and accompanying text.

15. Hodges observes that computers and biotechnology are treated differently in the written description cases, though he limits his focus primarily to biotechnology. Robert A. Hodges, Note, Black Box Biotech Inventions: When a "Mere Wish or Plan" Should be Considered an Adequate Description of the Invention, 17 GA. ST. U. L. REV. 831, 833 (2001). Others have complained that even within industries the standard may not be applied consistently. See, e.g., Glynn S. Lunney Jr., E-Obviousness, 7 MiCH. TELECOMM. \& TECH. L. REV. 363, 365 \& n.13 (2001).

16. The curious history of the patentability of software is discussed in detail elsewhere. See, e.g., GREGORY A. STOBBS, SOFTWARE PATENTS (1995); David S. Benyacar, Mathematical Algorithm Patentability: Understanding the Confusion, 19 RUTGERS COMPUTER \& TECH. L.J. 129 (1993); Donald S. Chisum, The Patentability of Algorithms, 47 U. PITT. L. REV. 959 (1986); Julie E. Cohen \& Mark A. Lemley, Patent Scope and Innovation in the Software Industry, 89 CAL. L. REV. 1 (2001); Irah H. Donner \& J. Randall Beckers, Throwing Out Baby Benson with the Bath Water: Proposing a New Test for Determining Statutory Subject Matter, 33 JURIMETRICS J. 247 (1993); Lee A. Hollaar, Justice Douglas Was Right: The Need For Congressional Action On Software Patents, 24 AIPLA Q.J. 283 (1996); Allen Newell, The Models Are Broken, The Models Are Broken!, 47 U. PITT. L. REV. 1023 (1986); Pamela Samuelson, Benson Revisited: The Case Against Patent Protection for Algorithms and Other Computer Program-Related Inventions, 39 EMORY L.J. 1025, 1033 n.24 (1990); Richard H. Stern, Tales from the Algorithm War: Benson to Iwahashi, It's Déjà Vu All Over Again, 18 AIPLA Q.J. 371 (1991); Jur Strobos, Stalking the Elusive Patentable Software: Are There Still Diehr or Was It Just a Flook?, 6 HARV. J.L. \& TECH. 363 (1993); John Swinson, Copyright or Patent or Both: An Algorithmic Approach to Computer Software Protection, 5 HARV. J.L. \& TECH. 145 (1991); Jonathan N. Geld, Note, General Does Not Mean Generic-Shedding Light on In re Alappat, 4 TEX. INTELL. Prop. L.J. 71 (1995); Maximilian R. Peterson, Note, Now You See It, Now You Don't: Was It a Patentable Machine or an Unpatentable "Algorithm"? On Principle and Expediency in Current Patent Law Doctrines Relating to ComputerImplemented Inventions, 64 GEO. WASH. L. REV. 90 (1995).

17. State Street Bank \& Trust v. Signature Fin. Group, 149 F.3d 1368, 1373 (Fed. Cir. 1998).

18. AT\&T Corp. v. Excel Communications, 172 F.3d 1352 (Fed. Cir. 1999). 
of patentable subject matter. In doing so, the court emphasized that it was deciding only the question of whether software was the sort of invention that could be patentable. ${ }^{19}$ It left the remaining patent validity issuesnotably novelty, ${ }^{20}$ nonobviousness, ${ }^{21}$ and compliance with the disclosure requirements $^{22}$ - to be worked out by the courts on a case-by-case basis. ${ }^{23}$

Section 112 of the Patent Act requires that patentees publish to the world a description of the invention sufficient to enable one of ordinary skill in the art to make and use it, and to include the "best mode" of implementing the invention. ${ }^{24}$ Indeed, this disclosure "bargain" between patentees and the public is central to patent policy. ${ }^{25}$ Disclosure serves two purposes. First, it permits competitors to make use of the patented invention once the patent expires, ensuring that the invention will ultimately enter the public domain. ${ }^{26}$ Second, it enables others to improve on the patented technology during the term of the patent itself, either by "designing around" the patent to produce a noninfringing variant or by developing a better version that, while infringing, is itself entitled to protection. ${ }^{27}$

19. State Street, 149 F.3d at 1373 . The categories of subject matter that are patentable are enumerated in 35 U.S.C. $\$ 101(2000)$.

20. 35 U.S.C. $\$ 102(2000)$.

21. 35 U.S.C. $\S 103(2000)$.

22. 35 U.S.C. $\S 112$ I $1(2000)$.

23. See State Street, 149 F.3d at 1375 . Indeed, on remand in $A T \& T$ the district court held the patent invalid under $\S 102$. AT\&T Corp. v. Excel Communications, 52 U.S.P.Q.2d 1865 (D. Del. 1999).

24. 35 U.S.C. $\$ 112 \uparrow 1(2000)$.

25. One classic justification for having a patent system is to encourage inventors to disclose their ideas to the public, who will benefit from this new knowledge once the patent expires. Kewanee Oil Co. v. Bicron Corp., 416 U.S. 470, 489 (1974) (referring to the "federal interest in disclosure" embodied in the patent laws); see also EDITH TILTON PENROSE, THE ECONOMICS OF THE INTERNATIONAL PATENT SYSTEM 31-34 (1951).

26. Without the disclosure obligation, patentees could conceivably keep the workings of their inventions secret, relying on that secrecy to extend protection even after the patent has expired. See Pitney-Bowes, Inc. v. Mestre, 701 F.2d 1365, 1372 n.12 (11th Cir. 1983) (discussing such policy concerns).

27. For a detailed discussion of how the law allocates rights between initial inventors and improvers, see, e.g., Howard F. Chang, Patent Scope, Antitrust Policy, and Cumulative Innovation, 26 RAND J. ECON. 34 (1995); Jerry R. Green \& Suzanne Scotchmer, On the Division of Profit in Sequential Innovation, 26 RAND J. ECON. 20 (1995); James B. Kobak Jr., Intellectual Property, Competition Law and Hidden Choices Between Original and Sequential Innovation, 3 VA. J. L. \& TECH. 6 (1998); Mark A. Lemley, The Economics of Improvement in Intellectual Property Law, 75 TEX. L. REV. 989 (1997); Clarisa Long, Proprietary Rights and Why Initial Allocations Matter, 49 EMORY L.J. 823 (2000); Robert P. Merges, Intellectual Property Rights and Bargaining Breakdown: The Case of Blocking Patents, 62 TENN. L. REV. 75 (1994); Robert P. Merges \& Richard R. Nelson, On the Complex Economics of Patent Scope, 90 CoLUM. L. REV. 839 
For software patents, however, a series of recent Federal Circuit decisions has all but eliminated the enablement and best mode requirements. In recent years, the Federal Circuit has held that software patentees need not disclose source or object code, flow charts, or detailed descriptions of the patented program. Rather, the court has found high-level functional descriptions sufficient to satisfy both the enablement and best mode doctrines. ${ }^{28}$ For example, in Northern Telecom, Inc. v. Datapoint Corp. ${ }^{29}$ the patent claimed an improved method of entering, verifying, and storing (or "batching") data with a special data entry terminal. The district court invalidated certain claims of the patent on the grounds that they were inadequately disclosed under $\S 112 .^{30}$ The Federal Circuit reversed. ${ }^{31}$ It held that when claims pertain to a computer program that implements a claimed device or method, the enablement requirement varies according to the nature of the claimed invention as well as the role and complexity of the

(1990); Suzanne Scotchmer, Standing on the Shoulders of Giants: Cumulative Research and the Patent Law, 5 J. ECON. PERSP. 29 (1991); Suzanne Scotchmer, Protecting Early Innovators: Should Second-Generation Products be Patentable?, 27 RAND J. ECON. 322 (1996).

On the importance of creative design-arounds for innovation, see WarnerJenkinson Co. v. Hilton Davis Chem. Co., 520 U.S. 17, 36 (1997), which contrasts "the intentional copyist making minor changes to lower the risk of legal action" with "the incremental innovator designing around the claims, yet seeking to capture as much as is permissible of the patented advance". See also Slimfold Mfg. Co. v. Kinkead Indus. Inc., 932 F.2d 1453, 1457 (Fed. Cir. 1991) ("Designing around patents is, in fact, one of the ways in which the patent system works to the advantage of the public in promoting progress in the useful arts, its constitutional purpose."); State Indus. v. A.O. Smith Corp., 751 F.2d 1226, 1236 (Fed. Cir. 1985) ("One of the benefits of a patent system is its socalled 'negative incentive' to 'design around' a competitor's products, even when they are patented, thus bringing a steady flow of innovations to the marketplace."); Matthew J. Conigliaro et al., Foreseeability in Patent Law, 16 BERKELEY TECH. L.J. 1045 (2001); Craig Allen Nard, Toward a Pragmatic Textualist Theory of Claim Interpretation, 14 HARV. J. L. \& TECH. 1, 40-43 (2000) ("The practice of designing around extant patents creates viable substitutes and advances, resulting in competition among patented technologies. The public clearly benefits from such activity.").

28. See Fonar Corp. v. General Electric Co., 107 F.3d 1543, 1549 (Fed. Cir. 1997); see also Lawrence D. Graham \& Richard O. Zerbe, Jr., Economically Efficient Treatment of Computer Software: Reverse Engineering, Protection, and Disclosure, 22 RUTGERS COMPUTER \& TECH. L.J. 61, 96-97 (1996); Anthony J. Mahajan, Note, Intellectual Property, Contracts, and Reverse Engineering After ProCD: A Proposed Compromise for Computer Software, 67 FoRDHAM L. REV. 3297, 3317 (1999).

29. 908 F.2d 931 (Fed. Cir. 1990), cert. denied, 498 U.S. 920 (1990).

30. Northern Telecom, Inc. v. Datapoint Corp., No. CA3-82-1039-D (N.D. Tex. Aug. 31, 1988).

31. 908 F.2d at 943 (Fed. Cir. 1990). 
computer program needed to implement it. ${ }^{32}$ Under the facts in this case, the court reasoned, the core of the claimed invention was the combination of components or steps, rather than the details of the program the applicant actually used. ${ }^{33}$ The court noted expert testimony that various programs could be used to implement the invention, and that it would be "relatively straightforward [in light of the specification] for a skilled computer programmer to design a program to carry out the claimed invention. ${ }^{, 34}$ The court continued:

The computer language is not a conjuration of some black art, it is simply a highly structured language . . The conversion of a complete thought (as expressed in English and mathematics, i.e. the known input, the desired output, the mathematical expressions needed and the methods of using those expressions) into a language a machine understands is necessarily a mere clerical function to a skilled programmer. $^{35}$

And in Fonar Corp. v. General Electric Co., ${ }^{36}$ involving the best mode requirement, the Court explained:

As a general rule, where software constitutes part of a best mode of carrying out an invention, description of such a best mode is satisfied by a disclosure of the functions of the software. This is because, normally, writing code for such software is within the skill of the art, not requiring undue experimentation, once its functions have been disclosed. It is well established that what is within the skill of the art need not be disclosed to satisfy the best mode requirement as long as that mode is described. Stating the functions of the best mode software satisfies that description test. We have so held previously and we so hold today. Thus, flow charts or source code listings are not a requirement for adequately disclosing the functions of software. ${ }^{37}$

Indeed, in a few cases the Federal Circuit has gone so far as to hold that patentees can satisfy the written description and best mode require-

32. Id. at 941 .

33. Id.

34. Id. at $941-42$.

35. Id. at 942 (quoting Ex rel Sherwood, 613 F.2d 809, 817 n.6 (C.C.P.A. 1980).

36. 107 F.3d 1543 (Fed. Cir. 1997).

37. Id. at 1549 (citations omitted). 
ments for inventions implemented in software even though they do not use the terms "computer" or "software" anywhere in the specification! $!^{38}$ To be sure, in these latter cases it would probably be obvious to one skilled in the art that the particular feature in question should be implemented in software, though it would not necessarily be obvious how to do so. One recent case suggests limits on this conclusion, holding that an oil drilling company failed to enable its method for calculating the location of a borehole when it kept all information about the computer programs used to perform the calculation secret. ${ }^{39}$ Still, it is remarkable that the Federal Circuit is willing to find the enablement requirement satisfied by a patent specification that provides no guidance whatsoever on how the software should be written. ${ }^{40}$

It is simply unrealistic to think that one of ordinary skill in the programming field can necessarily reconstruct a computer program given no more than the purpose the program is to perform. Programming is a highly technical and difficult art. Unfortunately, the Federal Circuit's peculiar direction in the software enablement cases has effectively nullified the dis-

38. See Robotic Vision Sys., Inc. v. View Eng'g, Inc., 112 F.3d 1163 (Fed. Cir. 1997) (best mode); In re Dossel, 115 F.3d 942 (Fed. Cir. 1997) (written description).

By contrast, in White Consol. Indus., Inc. v. Vega Servo-Control, Inc., 713 F.2d 788 (Fed. Cir. 1983), the Federal Circuit had invalidated a patent for a machine tool control system which was run by a computer program. Part of the invention was a programming language translator designed to convert an input program into machine language, which the system could then execute. The patent specification identified an example of a translator program, the so-called SPLIT program, which was a trade secret of the plaintiff. The court held that the program translator was an integral part of the invention, and that mere identification of it was not sufficient to discharge the applicant's duty under section 112. The court seemed concerned that maintaining the translator program as a trade secret would allow White to extend the patent beyond the 17-year term then specified in the patent code.

While White suggests that it is not sufficient merely to identify the program or its functions, more recent Federal Circuit authority is overwhelmingly to the contrary. See, e.g., In re Dossel, 115 F.3d at 946 (Fed. Cir. 1997) (deeming the disclosure that "known algorithms" can be used to solve standard equations which are known in the art" sufficient to satisfy the written description requirement, although the exact mathematical algorithm. .. was not).

39. See Union Pacific Resources v. Chesapeake Energy Corp., 236 F.3d 684, 690-92 (Fed. Cir. 2001). However, the court made it clear that only the general nature of the program, not the program itself, need be disclosed. Id. at 691 .

40. One recent decision even found that a specification that provided inconsistent and inaccurate guidance as to how the invention worked was not rendered indefinite by a lack of enablement. See S3 Inc. v. Nvidia Corp., 259 F.3d 1364 (Fed. Cir. 2001). But see $i d$. at 1371 (Gajarsa, J., dissenting). 
closure requirement for software patents. ${ }^{41}$ And since source code is normally kept secret, software patentees generally disclose little or no detail about their programs to the public. ${ }^{42}$ Software patentees during the $1980 \mathrm{~s}$ and early 1990 s tended to write their patents in means-plus-function for$\mathrm{mat}^{43}$ in order to satisfy the changing dictates of the Federal Circuit's patentable subject matter rules. ${ }^{44}$ Lawyers writing patents in such a format have an incentive to describe their invention in the specification in terms that are as general as possible, since means-plus-function claim elements will be limited to the actual structure disclosed in the specification and

41. A recent development in Federal Circuit jurisprudence may suggest another source for a robust disclosure obligation, however. The court has recently reinvigorated the written description requirement in $\S 112$ I, not only in biotechnology cases, see, e.g., Regents of the Univ. of Calif. v. Eli Lilly \& Co., 119 F.3d 1559 (Fed. Cir. 1997), but also in cases about other types of inventions, see, e.g., Gentry Gallery, Inc. v. Berkline Corp., 134 F.3d 1473 (Fed. Cir. 1998) (reclining chairs); Hyatt v. Boone, 146 F.3d 1348 (Fed. Cir. 1998) (computer chip); Purdue Pharma v. Faulding, Inc., 230 F.3d 1320 (Fed. Cir. 2000) (method of treating pain). Under those cases, a patent claim may be invalid in certain circumstances if the specification does not expressly describe what the claim covers, even if the specification gave sufficient information to enable the claim. See also Johnson \& Johnston Assoc. v. R.E. Service Co., 285 F.3d 1046 (Fed. Cir. 2001) (en banc) (equivalents disclosed in the patent but not claimed are dedicated to the public domain). We argue below that a broad reading of the written description requirement is largely unique to biotechnology cases and is primarily limited to those cases in which a patent claim is amended during prosecution to track a competitor's product. The cases so far suggest that the courts will not apply Eli Lilly to software. See In re Dossel, 115 F.3d 942, 946 (Fed. Cir. 1997) (rejecting written description argument in a software case, albeit before the Federal Circuit's more recent cases on the issue); Reiffin v. Microsoft Corp., 214 F.3d 1342, 1348 (Fed. Cir. 2000) (Newman, J., concurring) (arguing that Gentry Gallery does not create a new, stringent written description rule; the majority did not address the merits); Sun Microsystems v. Kingston Tech., 57 U.S.P.Q.2d 1822 (N.D. Cal. 2000) (holding that lack of written description does not invalidate software patent). If we are wrong, however, and cases like Eli Lilly represent a general rule, it could mean that most software patents will be held invalid for failure to describe the invention in any detail.

42. See, e.g., MElvin C. GARnER ET AL., Advanced Claim Drafting and Amendment Writing Workshop for Electronics and Computer-Related Subject Matter, in ADVANCED ClAiM AND AMENDMENT WRITING 1996, 227, 275 (PLI 1996) (source code listings in patents "are primarily a relic of the early days of computer program patents when it was unclear what would suffice for sufficiency of disclosure"); Thomas P. Burke, Note, Software Patent Protection: Debugging the Current System, 69 Notre DAME L. REV. 1115, 1158-60 (1994).

43. See 35 U.S.C. $\S 112$ \ $6(2000)$.

44. See, e.g., In re Alappat, 33 F.3d 1526 (Fed. Cir. 1994) (en banc). 
equivalents thereof. ${ }^{45}$ As a result, there is no easy way to figure out what a software patent owner has built except to reverse engineer the program. ${ }^{46}$

The court's reasoning in the enablement and best mode cases has another implication as well. Because the court views actually writing and debugging a program as a "mere clerical function" "within the skill of the

45. Id. at 1541 .

46. On the perils of reverse engineering patented software, see Cohen $\&$ Lemley, supra note 16, at 17-21. For discussions of how to satisfy the disclosure requirement in software patents, see Wesley L. Austin, Software Patents, 7 TEX. INTELL. PrOP. L.J. 225, 277 (1999); David Bender \& Anthony R. Barkume, Disclosure Requirements for Software-related Patents, 8 No. 10 COMPUTER LAW. 1 (1991); Michael Bondi, Upholding the Disclosure Requirements of 35 U.S.C. § 112 Through The Submission of Flow Charts with Computer Software Patent Applications, 5 SOFTwARE L.J. 635 (1992); D.C. Toedt III, Patents for Inventions Utilizing Computer Software: Some Practical Pointers, 9 No. 10 COMPUTER LAW. 12 (1992) (suggesting disclosure of 'pseudo-code,' i.e., generalized code not written in a particular programming language, to satisfy $\S 112$, and discussing pros and cons of disclosing actual source code). Thomas Burke provides a policy argument in favor of greater disclosure:

A software patent without source code is like a law review piece filled with case names but missing citations to case reporters. A person of ordinary skill in legal research might be able to track down the fulltext of all the opinions. Marbury v. Madison would be found quicker than a state trial court opinion. But, would anyone think that such a practice was enabling or the best mode? As it is now, the disclosure requirements can be met using such devices as specifications, flowcharts, and pseudo-code.

Professor Randall Davis of MIT summed it up at the National Research Counsel in 1990:

There is almost no way to visualize software. Sure, we have flow charts, we have data-flow diagrams, we have control flow diagrams, and everybody knows how basically useless those are. Flow charts are documentation you write afterward - because management requires them, not because they are a useful tool.

A patent is most similar to a real property deed specifying the metes and bounds for a parcel of land. Both documents are not easily understood but succeed if they secure the owners' interests in the specified claims. If the goal is to inform the world of an invention, software professionals have avenues more timely and less expensive than pursuing a patent application. In fostering the trade-off between the interests of inventors and the public, the source code is the best way to explain an algorithm.

Under this proposal, a computer system's complete source code would not have to be appendixed to the patent. The applicant would only have to include the source code directly relevant to enabling the claim language. In cases where claims are broadly written (as in a means-plus-function apparatus claim that covers the automation of an entire industry), a nearly complete program listing would be required.

Burke, supra note 42 , at $1158-60$. 
art," it seems to follow that the court is unlikely to consider the work of programming itself to be sufficiently innovative to meet the nonobviousness threshold of section 103. After all, much the same test for adequacy of disclosure-would one of ordinary skill in the art be able to make the patented invention without undue experimentation-is also central to the obviousness inquiry. ${ }^{47}$

While only a limited number of appellate decisions discuss obviousness in the context of software patents, there is some reason to believe that the court is imposing a rather strict standard. The first case involving the obviousness of a software-implemented invention is, perhaps surprisingly, a Supreme Court case from the 1970s. In Dann v. Johnston, ${ }^{48}$ the Court held a patent on a "machine system for automatic record-keeping of bank checks and deposits" invalid for obviousness. ${ }^{49}$ The Court took a rather broad view of obviousness in the computer industry, focusing on whether systems analogous to the patentee's had been implemented in computers before, rather than analyzing the precise differences between the patentee's program and the prior art programs. ${ }^{50}$ The clear implication of the opinion is that if a reasonably skilled programmer could produce a program analogous to the patented one, and if there was motivation in the prior art to do so when the program was written, the patented program is obvious and thus not patentable.

The Federal Circuit has found software patents invalid for obviousness in two recent cases, Lockwood v. American Airlines ${ }^{5 l}$ and Amazon.com $v$. Barnes \& Noble. ${ }^{52}$ Neither case opined directly on the ease with which computer programs could be produced, but both viewed obviousness as a rather substantial hurdle to patenting software. ${ }^{53}$ In Lockwood, the ques-

47. Compare In re Vaeck, 947 F.2d 488, $493-94$ (Fed. Cir. 1991) (levels of experimentation and skill in the art in obviousness test) with In re Wands, 858 F.2d 731, 736-37 (Fed. Cir. 1988) (levels of experimentation and skill in the art in enablement test). See also Donald S. Chisum, Anticipation, Enablement and Obviousness: An Eternal Golden Braid, 15 AIPLA Q.J. 57, 58 (1987) (discussing the fundamentally interrelated nature of the obviousness and enablement inquiries). equivalent.

We argue below, however, that the two PHOSITA standards are not necessarily

48. 425 U.S. 219 (1976).

49. Id. at $228-29$.

50. Id. at 220 .

51. 107 F.3d 1565 (Fed. Cir. 1997).

52. 239 F.3d 1343 (Fed. Cir. 2001).

53. See Lockwood, 107 F.3d at 1572; Amazon.com, 239 F.3d at 1359-60. In In re Zurko, 111 F.3d 887, 889 (Fed. Cir. 1997), the Federal Circuit held that a patented software invention was nonobvious even though each of the elements of the invention could be found in the prior art, because the prior art did not identify the problem to be solved. 
tion was whether the defendant's own system made the patented claims obvious. The system had been in public use, but American Airlines had kept the workings of the system secret. Nonetheless, because Lockwood's patent was claimed in broad functional terms, the court found that similarly broad functional disclosures in the prior art were sufficient to render the patent obvious. While Lockwood argued that the information provided was not sufficient for one skilled in the art to make and use the system, the court pointed out that it was as detailed as the information Lockwood's own patent provided. ${ }^{54}$ Thus, the patent's meager disclosure of technical details indirectly contributed to the court's finding of obviousness. In Amazon.com, the court found Amazon's "one-click" shopping feature to be obvious in view of certain references describing the desirability or feasibility of such a system in general terms, and one prior system that delivered data online in response to a mouse click. The court rejected arguments that the one-click feature was technically difficult to implement, relying on the fact that the prior art generally described such a system as both desirable and feasible. The court also gave surprisingly short shrift to Amazon's evidence of secondary considerations of nonobviousness. ${ }^{55}$

The likely result of the Federal Circuit's focus on high-level functionality is that improvements in programming techniques will be found obvious and thus not patentable in view of prior art that solved the same basic problem in a somewhat different way. This was arguably the result in both Dann and Lockwood, ${ }^{56}$ and it seems to follow from the court's view in the section 112 cases that programmers are an extremely skilled bunch needing little or no guidance from the prior art in order to implement a new idea in software. While disclosure is a minimal hurdle for software patents, then, obviousness can be a rather tough one. ${ }^{57}$

While Zurko certainly demonstrates that some software patents will be held nonobvious, it is a specific holding of rather limited utility to most software patentees.

54. See Lockwood, 107 F.3d at 1570.

55. Amazon.com, 239 F.3d at 1366. To be sure, the court may have treated Amazon's patent more harshly because the case arose on appeal from a preliminary injunction. The court suggested that preliminary injunctions should not be granted if there were any serious questions as to the validity of the patent. $I d$. at 1350-51. Whether it would apply such a strict test of obviousness after trial is not clear.

56. See also Electronic Planroom v. McGraw-Hill Cos., 135 F. Supp. 2d 805, 82627 (E.D. Mich. 2001).

57. The minimal disclosure requirement can create other problems for software patentees as well. For example, under the Supreme Court's decision in Pfaff v. Wells Electronics, 525 U.S. 55, 67 (1998), a $\S 102($ b) on sale bar is triggered when an invention that is put on sale is "ready for patenting." That in turn means that the patentee has prepared an enabling disclosure. $I d$. But since the standard for enabling disclosure is so low in software, it is very easy to trigger an on sale bar. But $c f$. Space Systems/Loral, Inc. v. 
This argument may strike the reader as somewhat surprising. After all, legions of scholars and commentators complain that the PTO is issuing too many software patents, and in particular that it is issuing patents on subject matter that should be considered obvious. ${ }^{58}$ We agree with these commentators that the PTO is issuing bad software patents, in part because it cannot find relevant prior art. ${ }^{59}$ But our point is a different one: those patents will not fare well in litigation because the Federal Circuit will con-

Lockheed Martin Corp., 271 F.3d 1076, 1080 (Fed. Cir. 2001) (holding in a computer hardware case that substantial description was required).

58. See, e.g., Julie E. Cohen, Reverse Engineering and the Rise of Electronic Vigilantism: Intellectual Property Implications of "Lock-Out" Technologies, 68 S. CAL. L. REV. 1091, 1178 (1995); Lunney, supra note 15, at 374; Robert P. Merges, As Many As Six Impossible Patents Before Breakfast: Property Rights for Business Concepts and Patent System Reform, 14 BERKELEY TECH. L.J. 577, 584-87 (1999).

59. A number of commentators have expressed concern about the difficulty PTO examiners have in finding software prior art. As Julie Cohen explains:

$[\mathrm{I}] \mathrm{n}$ the field of computers and computer programs, much that qualifies as prior art lies outside the areas in which the PTO has traditionally looked - previously issued patents and previous scholarly publications. Many new developments in computer programming are not documented in scholarly publications at all. Some are simply incorporated into products and placed on the market; others are discussed only in textbooks or user manuals that are not available to examiners on line. In an area that relies so heavily on published, "official" prior art, a rejection based on "common industry knowledge" that does not appear in the scholarly literature is unlikely. Particularly where the examiner lacks a computer science background, highly relevant prior art may simply be missed. In the case of the multimedia data retrieval patent granted to Compton's New Media, industry criticism prompted the PTO to reexamine the patent and ultimately to reject it because it did not represent a novel and nonobvious advance over existing technology. However, it would be inefficient, and probably impracticable, to reexamine every computer program-related patent, and the PTO is unlikely to do so.

Cohen, supra note 58, at 1178 (citations omitted). See also Cohen \& Lemley, supra note 16, at 42-44; Greg Aharonian, Legal Resources and Tools for Surviving Bad Patents, at http://www.bustpatents.com (last visited Oct. 12, 2002). But cf. John R. Allison \& Mark A. Lemley, Who's Patenting What? An Empirical Exploration of Patent Prosecution, 53 VAND. L. REV. 2099, 2131-32 (2000) (noting that software patents actually cite slightly more nonpatent prior art than other types of patents do). 
sider them obvious in view of any other computer program that implements the same basic concepts, regardless of how different those programs are in detailed implementation, or perhaps even in view of prior art merely suggesting the desirability of such a program. Further, while hidden prior art is indeed a problem, parties in litigation have far more time and money to spend than do patent examiners, and they are much more likely than the PTO to find the best prior art. ${ }^{60}$ The probable result is that, while numerous software patents will issue, a large number of those actually litigated will be found obvious and thus invalid.

The court's assumption that programmers are extremely skilled may have other implications as well. For example, under Pfaff $v$. Wells Electronics, ${ }^{61}$ an invention is "on sale" for purposes of the $\S 102(\mathrm{~b})$ statutory bar when it is "ready for patenting." order for a software invention to be described or enabled, programmers may find that they put a not-yet-written computer program on sale-and therefore potentially lost their patent rights-merely by describing it in broad functional terms in a commercial communication.

Patent scope is necessarily interrelated with obviousness and enablement. ${ }^{63}$ The breadth of patent protection is in part a function of how different the invention is from the prior art. Further, patent claims are invalid if they are not fully described and enabled by the patent specification, so the permissible breadth of a patent will be determined by how much information the court determines must be disclosed to enable one of ordinary skill in the art to make and use the patented invention. The scope of the doctrine of equivalents is also a function of obviousness and enablement, since a patentee is not permitted to capture ground under the doctrine of equivalents that it would not have been permitted to claim in the first place. ${ }^{64}$

The Federal Circuit's treatment of software validity issues suggests that while the court will find relatively few software patents nonobvious, those that it does approve will be entitled to broad protection. The Federal Circuit's decisions strongly suggest that a patent is nonobvious only if it is the first program to perform a given function. Most patents will not meet this test, of course, but those that do will not be constrained by prior art to

60. See, e.g., Mark A. Lemley, Rational Ignorance at the Patent Office, 95 Nw. U. L. REV. 1495 (2001).

61. 525 U.S. 55 (1998).

62. 35 U.S.C. \& 102(b) (2000).

63. See Chisum, supra note 47.

64. See Wilson Sporting Goods v. David Geoffrey \& Assoc., 904 F.2d 677 (Fed. Cir. 1990). 
claim only their particular implementation of a function. They can claim the function itself. And the fact that they give little or no description of how to achieve this function will be no bar to the broad claims because the Federal Circuit has proven remarkably unwilling to require software patentees to disclose details. As a result, we should expect the first programmer to implement a new idea in software to claim the entire category of software, regardless of how second-comers actually implement the same concept.

The evidence on software patent claim scope so far is mixed, though there is some evidence tending to support this hypothesis. Most notably, in Interactive Gift Express v. Compuserve, ${ }^{65}$ the patentee had designed a kiosk system for printing copyrighted works on demand. The Federal Circuit held that the claims of the patent should be read broadly, to cover any form of online downloading in response to a remote request. ${ }^{66}$ In doing so, it reversed the district court's construction of five separate claim elements. As construed by the Federal Circuit, the patent is breathtaking in its scope, and most electronic commerce sites that permit downloading of digital information are likely within its ambit.

The court's treatment of software patent scope under the doctrine of equivalents has been less uniform. Many of these decisions have rejected the application of the doctrine of equivalents to read claim language written for one product generation at such a high level of abstraction that it covers accused products from a different generation. Thus, in Alpex Computer Corp. v. Nintendo Co. ${ }^{67}$ the Federal Circuit held that a patent claim to a video game output display system was not infringed by a nextgeneration system that worked in a different way. Alpex's claimed system included a display RAM that stored information corresponding to each pixel of a television screen in a discrete location. Nintendo's accused device, by contrast, used shift registers to store one "slice" of the video display at any given time. The Federal Circuit rejected a jury finding that the two systems were equivalent. ${ }^{68}$ In Digital Biometrics, Inc. v. Identix,

65. 256 F.3d 1323 (Fed. Cir. 2001).

66. Id.

67. 102 F.3d 1214 (Fed. Cir. 1996).

68. Id. at 1222. To similar effect as Alpex is Wiener v. NEC Electronics, Inc., 102 F.3d 534 (Fed. Cir. 1996). In that case, the Federal Circuit upheld the district court's finding of noninfringement under the doctrine of equivalents, because there were substantial differences between the patent's requirement that a computer program "call on" columns of data one byte at a time and the defendant's product, in which the columns alleged to be equivalent were not in the data matrix, and therefore were not called upon to read data. The court rejected the "conclusory" declaration of plaintiff's expert that the two processes were identical. 
Inc., ${ }^{69}$ the court likewise construed narrowly a patent claim to "image arrays" which stored a two-dimensional slice of video data, and which were merged into a "composite array" for storing a fingerprint image. The court held that the defendant's systems, which constructed the composite array directly rather than by using two-dimensional slices, did not create "image arrays" within the meaning of the claims. More recently, in Wang Laboratories, Inc. v. America Online ${ }^{70}$ the court affirmed a district court decision granting summary judgment of noninfringement under the doctrine of equivalents. The patent claims in that case covered "frames," defined in the specification as pages encoded in character-based protocols. The court rejected Wang's attempt to extend the patent to cover bit-mapped pages, crediting evidence that there were "huge, huge differences" between the two approaches. ${ }^{71}$

Other cases have applied the doctrine of equivalents more broadly. In some of those cases, the Federal Circuit has found equivalence between two different types of software programs written in different product generations. More troubling, some cases suggest that software implementations of certain ideas are equivalent to older mechanical implementations. An example is Overhead Door Corp. v. Chamberlain Group, Inc., ${ }^{72}$ where the patented system claimed a (mechanical) switch connected to a microprocessor that could store the codes of multiple garage doors. The Federal Circuit held that the claim was not literally infringed by an electronic switch implemented in software. However, the court reversed a grant of summary judgment to the defendants under the doctrine of equivalents, concluding that a reasonable jury could find that the difference between mechanical and software implementations was a mere "design choice."

69. 149 F.3d 1335 (Fed. Cir. 1998).

70. 197 F.3d 1377 (Fed. Cir. 1999).

71. Id. at 1386. See also Netword LLC v. Centraal Corp., 58 U.S.P.Q.2d 1076 (Fed. Cir. 2001) (claim requiring caching of data by local servers that pulled information from a central registry not infringed under the doctrine of equivalents by a system in which all local computers hold full copies of the central registry).

In a related context (interpreting equivalent structure in a means-plus-function claim), the court held that Nintendo's video game systems did not infringe GE's television switch patents because the patents, written in means-plus-function format, did not disclose a function for the switches identical to Nintendo's function. See General Electric Co. v. Nintendo Co., 179 F.3d 1350, 1363 (Fed. Cir. 1999). On how the doctrine of equivalents differs from equivalence under a means-plus-function analysis, see Chiuminatta Concrete Concepts, Inc. v. Cardinal Indus., 145 F.3d 1303 (Fed. Cir. 1998).

72. 194 F.3d 1261 (Fed. Cir. 1999). 
WMS Gaming, Inc. v. International Game Technology $y^{73}$ is also instructive. In that case, the court held that a claim written in means-plusfunction language that relied for its corresponding structure on a computer programmed with a particular algorithm was limited in literal scope to the particular algorithm chosen and equivalents thereof. However, the court found the defendant's algorithm infringing under the doctrine of equivalents, presumably because it was largely indifferent to which algorithm implemented the function of the program. This latter approach has the potential to expand the scope of patents in the software industry dramatically. $^{74}$

Software patents, then, are likely to face serious obviousness hurdles. The few patents that overcome those hurdles need disclose virtually nothing about the detailed workings of their invention, and will likely be broadly interpreted to cover a variety of algorithms and program structures for implementing the basic software invention. We would expect the outcome of such a patent policy to be an industry dominated by a relatively small number of broad patents. But this is not the inescapable result arising from application of current patent doctrines, as we see when we turn to consider the Federal Circuit's contemporary treatment of a different sector, biotechnology.

\section{Biotechnology Patent Cases ${ }^{75}$}

In contrast to the Federal Circuit decisions regarding software, recent decisions involving genetic material have imposed a stringent disclosure standard for patenting macromolecules. ${ }^{76}$ The Court has placed particular

73. 184 F.3d 1339 (Fed. Cir. 1999).

74. For an argument that a variety of structural tendencies are likely to drive the courts to read software patent claims broadly under the doctrine of equivalents, see Cohen \& Lemley, supra note 16, at 39-50.

75. For background on the science of biotechnology, see generally ROBERT P. Merges, et Al., Intellectual Property in the New TeChNological Age: 2002 CASE AND Statutory Supplement 501-16 (2001); Dan L. Burk, A Biotechnology Primer, 55 U. PITT. L. REV. 611 (1994).

76. We acknowledge Lawrence Sung's contrary view, that the Federal Circuit's biotechnology cases are simply decided on their individual facts and do not reflect any patterns. See Sung, infra note 188, at 107. See also John W. Schlicher, Biotechnology and the Patent System: Patent Law and Procedures for Biotechnology, Health Care and Other Industries, 4 U.BALT. INTELL. PROP. L.J. 121, 127 (1996) ("I do not understand the Court of Appeals for the Federal Circuit to have created a subset of patent law doctrines for biotechnology."). But other commentators appear to recognize that something unusual is happening in the case of biotechnology. See, e.g., Hodges, supra note 15, at 832; Janice M. Mueller, The Evolving Application of the Written Description Requirement to Biotechnological Inventions, 13 BERKELEY TECH. L.J. 615 (1998); Harris A. Pitlick, The 
emphasis on the "written description" requirement of section 112, which requires the patentee to specifically describe the claimed invention as part of the disclosure. The justification for such a detailed description is to demonstrate to others of ordinary skill that the inventor in fact has the invention in her possession; the assumption being that a sufficiently detailed description would not be possible if the inventor were speculating or guessing about its features. ${ }^{77}$ This requirement is separate from (and potentially more stringent than) the enablement requirement. Although the two are closely connected, satisfying one requirement does not necessarily satisfy the other. The classic example offered by one court is the situation in which the description of a particular chemical compound enables one of ordinary skill to make other, related, compounds, yet those other compounds are not described in the patent disclosure. The first compound is both enabled and described; the others are only enabled. ${ }^{78}$

This venerable chemical patenting hypothetical has been brought to life by the Federal Circuit's biotechnology opinions. For example, in Fiers v. Revel, ${ }^{79}$ the court considered the decision of the Patent Office in a threeway interference over patent applications claiming the human DNA sequence that produces the protein fibroblast beta-interferon $(\beta-I F) .{ }^{80}$ One of the applicants, Revel, relied for priority upon his Israeli patent application, which disclosed methods for isolating a fragment of the DNA sequence coding for $\beta$-IF and for isolating messenger RNA coding for $\beta$-IF. The court considered whether the disclosure in Revel's Israeli application satisfied the U.S. written description requirement and could therefore support a U.S. application. The Federal Circuit upheld a determination by the Board of Patent Appeals and Interferences that Revel's disclosure was not an adequate description, largely because it failed to disclose the actual se-

Mutation on the Description Requirement Gene, 78 J. PAT. \& TRADEMARK OFF. SOC'Y 209 (1998); Margaret Sampson, The Evolution of the Enablement and Written Description Requirements Under 35 U.S.C. $\$ 112$ in the Area of Biotechnology, 15 BERKELEY TECH. L.J. 1233 (2000). It seems readily apparent to us, as to the majority of other commentators, that the biotechnology cases consistently depart from the standards applied in other industries.

77. Of course, in the case of constructive reduction to practice, or filing a "paper patent" without having actually made the invention, the inventor is in some sense speculating or guessing about the features of an invention not yet built. But even in that instance, the underlying assumption in patent law is that the inventor "has" the invention mentally, and so can give a sufficiently detailed description of that inventive conception-physically creating the invention is straightforward.

78. In re DiLeone, 436 F.2d 1404, 1405 n.1 (C.C.P.A. 1971).

79. Fiers v. Revel, 984 F.2d 1164 (Fed. Cir. 1993).

80. In biotechnology terms, we say that the DNA sequence in question "codes for" the protein. 
quence of the DNA molecule at issue. According to the court's reasoning, disclosing a method for obtaining the molecule was not the same as disclosing the molecule itself:
An adequate written description of a DNA requires more than a mere statement that it is part of the invention and reference to a potential method for isolating it; what is re- quired is a description of the DNA itself. . A bare reference to a DNA with a statement that it can be obtained by re- verse transcription is not a description; it does not indicate that Revel was in possession of the DNA. ${ }^{81}$

Since the Revel application did not disclose the sequence for the molecule claimed, the court characterized it as disclosing merely "a wish, or arguably a plan, for obtaining the DNA." ${ }^{82}$ Under Fiers, an inventor does not conceive of a DNA invention until she actually creates it. ${ }^{83}$

A similar conclusion was reached in a subsequent case, Regents of the University of California $v$. Eli Lilly. ${ }^{84}$ The patent at issue covered a microorganism carrying the DNA sequence coding for human insulin. The patentee supported this claim by disclosing a method for obtaining the human cDNA $^{85}$, as well as the amino acid sequences for the insulin protein and the corresponding insulin DNA sequence in rats. Relying on the Fiers opinion, the court concluded that the written description requirement again was not met: "Describing a method of preparing a cDNA or even describ-

81. Fiers, 984 F.2d at 1170-71.

82. Id.

83. See also Adang v. Fischhoff, 286 F.3d 1346 (Fed. Cir. 2002) (disclosure of genetically altered tobacco plant did not enable claim to genetically altered tomato plant); Hitzeman v. Rutter, 243 F.3d 1345 (Fed. Cir. 2001) (conception of biotechnology invention simultaneous with reduction to practice). To be sure, the court stopped short of creating an absolute rule, noting that " $[t]$ here may be situations where an organism's performance of certain intracellular processes might be reasonably predictable, and evidence of such predictability might be sufficient to support a finding of conception prior to reduction to practice." Id. at 1357. But even here the court's language focuses on organic processes, not DNA sequences.

84. 119 F.3d 1559 (Fed. Cir. 1997).

85. cDNA, or complementary DNA, is produced by reverse transcribing the messenger RNA transcript of genomic DNA. DAVID FREIFELDER \& GEORGE M. MALACINSKI, ESSENTIALS OF MOLECULAR BIOLOGY 278 (2d ed. 1993). This process reverses the usual flow of genetic information from DNA to RNA, but the cDNA transcript is not necessarily identical to the genomic DNA template, as the mRNA sequence may have been edited after translation. $I d$. 
ing the protein that the cDNA encodes, as the example does, does not necessarily describe the DNA itself." 86

In reaching these results, the Federal Circuit has been adamant that the degree of specificity required for an adequate description of nucleic acids requires description of "structure, formula, chemical name, or physical properties." ${ }^{87}$ In Eli Lilly, because "[n]o sequence information indicating which nucleotides constitute human cDNA appears in the patent .. the specification does not provide a written description of the invention." The court in such cases seems particularly incensed by applicants who designate a macromolecule by generic or functional terms, such as "vertebrate insulin cDNA":

A definition by function .. is only an indication of what the gene does, rather than what it is. It is only a definition of a useful result rather than a definition of what achieves that result. Many such genes may achieve that result. The description requirement of the patent statute requires a description of an invention, not an indication of a result that one might achieve if one made that invention. Accordingly, naming a type of material generally known to exist, in the absence of knowledge as to what that material consists of, is not a description of that material. ${ }^{89}$

Such failure to describe more than one or two nucleotides is a particular problem where the patent claims are drawn to a broad class of nucleotides. For example, Revel's claim covered all DNA molecules that code for $\beta-I F$, but "[c]laiming all DNAs that achieve a result without defining what means will do so is not in compliance with the description requirement; it is an attempt to preempt the future before it has arrived." 90

The Federal Circuit's construction of the written description requirement as requiring precise sequence data gains particular significance whenever claims are drawn to an entire genus, or family, of molecules. The patent discussed in the Eli Lilly written description analysis claimed a broad family of DNA molecules coding for insulin in different mammalian species, but it disclosed only one species of DNA, that coding for rat insulin. The court held this to be insufficient to describe the broad class of cDNAs coding for mammalian or vertebrate insulin. ${ }^{91}$ Although declining

86. Fiers, 984 F.2d at 1170-71.

87. Id. at 1171 .

88. Eli Lilly, 119 F.3d at 1567.

89. Id. at 1568 (citations omitted).

90. Fiers, 984 F.2d at 1171.

91. Eli Lilly, 119 F.3d at 1567. 
to specify exactly what would be needed to support a broad claim, the court cited previous chemical cases dealing with related groups of small molecules. Based on these cases, the court declared that macromolecules should be treated in the same fashion: the patentee need not show every member of a claimed genus, but is required to show a "representative" number of cDNAs illustrating or defining the common structural features of a "substantial" portion of the genus."

A similarly broad claim was rejected in the Amgen case as failing the standard for enablement rather than written description. ${ }^{93}$ There, the patentee claimed nucleic acid sequences coding for the protein erythropoetin or for other proteins with the same biological function. The trial judge concluded that because Amgen was unable to specify which analogs might have the biological properties claimed, the claims were not enabled. ${ }^{94}$ The Federal Circuit panel, however, held that the district court had reached the right conclusion for the wrong reason. While the district court focused on the thousands of EPO analogs that could be created by substituting amino acid residues in the polypeptide chain, the appellate court focused on the patentee's failure to disclose the DNA molecules that would code for those analogs. ${ }^{95}$ Since the claims were directed to DNA sequences, the issue was not the enablement of the EPO analogs, but rather the enablement of the myriad DNA sequences, which the court held could not be made and used on the basis of a few examples. ${ }^{96}$

In an important recent decision, the Federal Circuit backed off somewhat from its categorical insistence on structure in biotechnology disclosure cases. In Enzo Biochem v. Gen-Probe,${ }^{97}$ the court adopted the PTO's Guidelines on Written Description. ${ }^{98}$ Those Guidelines provide that biotechnology inventions normally must be described by structure, but may also be described by "functional characteristics when coupled with a known or disclosed correlation between function and structure." court specifically identified antibody claims as ones that might be de-

92. Id. at 1569. Cf. Amgen, Inc. v. Hoechst Marion Roussel, Inc., 126 F. Supp. 2d 69 (D. Mass. 2001) (finding patent for urinary erythropoietin preparations invalid under written description requirement because different preparations vary in glycosylation).

93. Amgen, Inc. v. Chugai Pharm. Co., 927 F.2d 1200, 1212 (Fed. Cir. 1991).

94. Id. at 1205 .

95. Id. at 1212-14.

96. Id.

97. 296 F.3d 1316 (Fed. Cir. 2002).

98. Id. at 1324-25.

99. U.S. Patent \& Trademark Office, Guidelines for the Examination of Patent Applications Under the Written Description Requirement, 66 Fed. Reg. 1099, 1106 (Jan. 5, 2001). 
scribed by function-i.e., by describing the antigen to which they bind. ${ }^{100}$ Its holding was more limited, however. It held that the deposit of three actual DNA sequences created a factual question as to whether the deposited sequences could satisfy the written description requirement for claims covering those sequences and a broader genus. Because the deposited sequences inherently included the structure of the gene, the court in Enzo had no opportunity to endorse claims based entirely on proof of function rather than structure. The court did not repudiate, and indeed relied upon, the Eli Lilly baseline rule that disclosure of structure was required.

The same concerns that characterize the Federal Circuit's jurisprudence of biotechnology disclosure - the inadequacy of methodological disclosure, the requirement to specify sequence or structure, and uncertainty of selection within large classes of homologous molecules-have shaped the Federal Circuit's biotechnology obviousness cases. However, in the case of obviousness, the issue has been the presence of such factors in the prior art, rather than in the inventor's disclosure. Thus, the Federal Circuit held in In re Bell that a claim to DNA coding for human insulinlike growth factor (hIGF) was not obvious even though the prior art disclosed the amino acid sequence for the hIGF proteins and a method for using that information to obtain the corresponding DNA molecule. ${ }^{101} \mathrm{Un}$ der similar facts in In re Deuel, the court found claims directed to DNA coding for heparin binding growth factors (HBGFs) were not obvious in light of prior art disclosure of a partial amino acid sequence and a method for using that information to obtain the corresponding DNA molecule. ${ }^{102}$

Each decision rested largely upon the court's perception that the actual sequence of the claimed DNA molecules was uncertain or unpredictable from the prior art. In both cases the court dismissed as irrelevant the biological relationship between the molecules disclosed in the prior art and those claimed by the patent. The amino acid sequences of the proteins disclosed in the prior art are ultimately determined by the sequence of RNA nucleotides coding for the protein, which is in turn determinative of the cDNA claimed in the patent. ${ }^{103}$ The correspondence of nucleotide se-

100. Enzo, 296 F.3d at 1324.

101. See In re Bell, 991 F.2d 781, 784 (Fed. Cir. 1993).

102. See In re Deuel, 51 F.3d 1552 (Fed. Cir. 1995).

103. Neither Bell nor Deuel dealt with genomic DNA (gDNA) sequences, which are transcribed by cellular proteins to produce a messenger RNA molecule. See FREIFELDER \& MALACINSKI, supra note 85 (describing the transcription process). Both cases considered nonnaturally occurring cDNA sequences, which are reverse transcribed from messenger RNAs. The correspondence between gDNA and RNA may be very different than that of cDNA to RNA, especially in eukaryotic organisms where the processing of RNA transcripts may be extensive. Id. 
quences to amino acid sequences is well known as key to the "central dogma" of molecular biology: the transfer of genetic information from DNA to RNA to protein chains. However, particular amino acids can correspond to more than one nucleotide sequence, introducing uncertainty into the inverse relationship: that of amino acid sequence to nucleotide sequence. Because of this redundancy or "degeneracy" in the genetic code, the court noted in Bell that a vast number of possible sequences -about $10^{36}$-might code for the protein sequences disclosed in the prior art. The plaintiff claimed only one of these, in essence having searched among a large number of possibilities to select the particular cDNA sequence coding for hIGF.

Numerous commentators have pointed out that such a search is relatively routine using tried and true techniques of molecular biology. ${ }^{104}$ But prior art disclosure of a method, even an admittedly obvious method, was held insufficient to cure such uncertainty of structure. In rejecting the DNA claims in Bell and Deuel, the court rejected "the PTO's focus on known methods for potentially isolating the claimed DNA molecules" as "misplaced because the claims at issue define compounds, not methods." ${ }^{105}$ Prior to Bell, the opinion in Amgen had stressed the uncertainty of the methods for gene location available at the time of invention: while "it might have been feasible, perhaps obvious to try, to successfully probe a human gDNA library with a monkey cDNA probe, it does not indicate that the gene could have been identified and isolated with a reasonable likelihood of success. . there was no reasonable expectation of success in obtaining the EPO gene by the method that Lin eventually used."106 The court arguably just got the science wrong; by the time of the research at issue in Bell, such methods for searching a large universe of molecules were perhaps painstaking and time-consuming, but had an established likelihood of success.

Yet the court defined the issue in Bell and Deuel not as a matter of the uncertainty of obtaining a particular sequence, but of the uncertainty of predicting or visualizing from the prior art what sequence would be found.

104. See, e.g., Anita Varma \& David Abraham, DNA is Different: Legal Obviousness and the Balance Between Biotech Inventors and the Market, 9 HARV. J.L. \& TECH. 53 (1996); PhilipPe G. DuCoR, PAtenting the Recombinant Products of BiotechnolOGY (1998); Arti K. Rai, Intellectual Property Rights in Biotechnology: Addressing New Technology, 34 WAKE Forest L. REV. 827 (1999); Arti K. Rai, Addressing the Patent Gold Rush: The Role of Deference to PTO Patent Denials, 2 WASH. U.J.L. \& POL'Y 199 (2000).

105. In re Deuel, 51 F.3d at 1558; see also In re Bell, 991 F.2d at 785.

106. Amgen, Inc. v. Chugai Pharm. Co., 927 F.2d at 1208-09. 
Even in the Amgen opinion, the court hinted that the key to macromolecular obviousness lay in the prediction of an exact sequence, as "[n]either the DNA nucleotide sequence . . nor its exact degree of homology with the [prior art] monkey EPO gene was known at the time." 107 And in Deuel, the court explicitly held that "until the claimed molecules were actually isolated and purified, it would have been highly unlikely for one of ordinary skill in the art to contemplate what was ultimately obtained. What cannot be contemplated or conceived cannot be obvious." 108 Thus a likelihood-or even a certainty - of finding a DNA molecule with particular properties was deemed essentially irrelevant to whether structural claims to that molecule are obvious. ${ }^{109}$

The corollary to this holding is that a molecule will be obvious if the sequence is discernible in the prior art, even if its function is not. Prior art description of the "general idea of the claimed molecules, their function, and their general chemical nature" $" 10$ is insufficient to render a molecule obvious. Some commentators have suggested that this formulation of obviousness stands some danger of collapsing into the standard for anticipation; ${ }^{111}$ under section 102 of the Patent Act, an invention lacks patentable novelty if its elements are fully described in a prior art reference, and the Federal Circuit's obviousness requirement could be read to require such a prior art anticipation as the effective standard for obviousness. ${ }^{112}$ But unlike the requirements for anticipation, the Federal Circuit's biotechnology obviousness standard appears to require that the sequence of the DNA be predictable from the prior art, and not necessarily explicitly described. For example, the court in Deuel suggests that for "a protein of sufficiently small size and simplicity ... lacking redundancy, each possible DNA would be obvious over the protein." "113 Although the Federal Circuit has

107. Id.

108. $51 \mathrm{~F} .3 \mathrm{~d}$ at 1558 (emphasis added).

109. Cf. Rhone-Poulenc Agro v. DeKalb Genetics Corp., 272 F.3d 1335, 1357-58 (Fed. Cir. 2001) (holding that addition of second transit peptide to string of amino acids with transit peptide and fragment of a second transit peptide was not obvious because the amino acids were structurally different).

110. In re Deuel, 51 F.3d at 1558.

111. See Rebecca Eisenberg \& Robert P. Merges, Opinion Letter as to the Patentability of Certain Inventions Associated with the Identification of Partial cDNA Sequences, 23 AIPLA Q.J. 1, 32 (1995).

112. Indeed, the Federal Circuit has several times suggested that the two patent standards are closely linked, characterizing obviousness as a sort of continuum with anticipation as the 'epitome' or 'ultimate' endpoint of obviousness. See, e.g., In re Baxter Travenol Labs, 952 F.2d 388 (Fed. Cir. 1991); Jones v. Hardy, 727 F.2d 1524 (Fed. Cir. 1984); Connell v. Sears, Roebuck \& Co., 722 F.2d 1542 (Fed. Cir. 1983).

113. $51 \mathrm{~F} .3 \mathrm{~d}$ at 1559. 
not explicitly held so, one would also suspect that disclosure in the prior art of a substantial number of homologous sequences would render a new homologue predictable, and so render it obvious-just as the court has held that disclosure of a substantial number of homologues is enough to satisfy the written description requirement for a genus of homologues.

The Federal Circuit's biotechnology obviousness cases are all of a piece with the court's earlier holdings, such as the rejection on disclosure grounds of Revel's claim to all DNA sequences coding for $\beta$-IF. ${ }^{114}$ Due to degeneracy in the genetic code, Revel could not adequately describe the claimed invention as DNA coding for $\beta$-IF; an astronomically large number of possible sequences might do so. And if a functional or narrative description in a patent is insufficient to properly describe a DNA molecule coding for $\beta$-IF, the presence of a functional or narrative description of $\beta$ IF protein in the prior art seems insufficient to render the molecule obvious. According to the court, one cannot describe what one has not conceived, and what cannot be contemplated or conceived cannot be obvious. Just as disclosure in a patent of a method for obtaining a particular cDNA is inadequate to properly describe the invention, so disclosure in the prior art of a method for obtaining a particular cDNA cannot render the claimed invention obvious.

The conceptual linkage of obviousness and enablement to the depiction of macromolecular sequences in, respectively, the prior art or the patent disclosure, dictates a particular and predictable result for the availability and scope of such biotechnology patents. The expected outcome is that DNA patents will be numerous but extremely narrow. Under the Federal Circuit's precedent, a researcher will be able to claim only sequences disclosed under the stringent written description rules- the actual sequence in hand, so to speak. And as Judge Learned Hand observed long ago, a claim that covers only the thing invented is a weak claim indeed. ${ }^{115}$ At the same time, the inventor is shielded from obviousness by the lack of such explicit and detailed disclosure in the prior art. This lack of effective prior art seems to dictate that anyone who has isolated and characterized a novel DNA molecule is certain to receive a patent on it. But the inventor is certain to receive a patent only on that molecule, as the Federal Circuit appears to regard other related molecules as inadequately described until their is sequence is disclosed.

114. See discussion supra notes 79-86.

115. See Philip A. Hunt Co. v. Mallinckrodt Chem. Works, 177 F.2d 583, 585-86 (2d Cir. 1949) (noting that it may be impossible to write claims of appropriate scope without using functional language to describe variants). 
The set of axioms underlying this set of results forms a logical framework that may be extended to certain other biotechnology inventions. For example, one would conclude from the Federal Circuit's analysis in these cases that a cDNA should be obvious in light of its corresponding $\mathrm{mRNA}^{116}$, since the former is reverse transcribed from the latter, and there is no redundancy or degeneracy in the correspondence between the nucleotides in the two molecules. ${ }^{117}$ However, an mRNA or corresponding cDNA need not render obvious the genomic DNA (gDNA) from which it is derived, since in many organisms, the gDNA will include intervening sequences, or introns, that are not predictable from the mRNA sequence.

Perhaps more important than the extension of the Federal Circuit's logic to other classes of molecules is the extension of its logic to other patent doctrines. For example, as we have indicated with regard to software, patent scope is a function of the obviousness and written description requirements. Under the court's decisions, the literal scope of biotechnology patents will be quite narrow: patent claims are confined to the DNA sequences actually generated and disclosed, rather than those enabled by the patentee. While that scope may be broadened by the doctrine of equivalents, ${ }^{18}$ the recent trend to limit the scope of the doctrine of equivalents ${ }^{119}$ may mean that the biotechnology industry will be characterized by large numbers of narrow patents.

116. mRNA, or messenger RNA, is the complementary molecule produced from transcription of genomic DNA. See FREIFELDER \& MALACINSKI, supra note 85, at 159.

117. Lubert Stryer, BIOChemistry 132 (3d ed. 1988); JAMES D. WATSON, ET AL., Molecular Biology OF THE GENE 610-11 (4th ed. 1987).

118. The very parsimonious reading that the Federal Circuit gives to obviousness in biotechnology cases seems to leave wide latitude for findings of equivalence in nucleotide infringement cases. See Wilson Sporting Goods Co. v. David Geoffery \& Assoc., 904 F.2d 677 (Fed. Cir. 1990) (testing equivalence by inquiring whether a hypothetical claim encompassing the accused product would have been obvious at the time of invention).

119. The courts have recently strengthened other limits on the doctrine of equivalents, notably prosecution history estoppel and the doctrine of dedication to the public domain. See, e.g., Festo Corp. v. Shoketsu, 535 U.S. 722 (2002) (prosecution history estoppel applies broadly); Johnson \& Johnston Assoc. v. R.E. Serv. Co., 238 F.3d 1347 (Fed. Cir. 2001) (en banc) (equivalents disclosed in the patent but not claimed are dedicated to the public domain). See also Matthew J. Conigliaro et al., Foreseeability in Patent Law, 16 BERKELEY TECH. L.J. 1045 (2001) (discussing both doctrines). Those limitations may prevent any patent from being read too broadly under the doctrine of equivalents. 


\section{The Divergent Standards}

Patent practitioners often focus on a single technology area, and so may tend to take the court's rules in that area for granted. Even a casual juxtaposition of the biotechnology and software cases, however, shows dramatic differences in applying what are nominally the same legal rules. ${ }^{120}$ District courts have recognized the difference, applying the Federal Circuit rules in different ways depending on the technology at issue. ${ }^{121}$ The easiest way to see this difference may be to imagine the court's language from one discipline applied to another. In Fonar, for instance, the court said:

As a general rule, where software constitutes part of a best mode of carrying out an invention, description of such a best mode is satisfied by a disclosure of the functions of the software. This is because, normally, writing code for such software is within the skill of the art, not requiring undue experimentation, once its functions have been disclosed. ${ }^{122}$

120. Commentators have observed that the Federal Circuit's biotechnology written description cases apply a standard quite different from the written description precedent in other areas. See, e.g., Mueller, supra note 76; Sampson, supra note 76; Limin Zheng, Note, Purdue Pharma L.P. v. Faulding Inc., 17 BERKELEY TECH. L.J. 95, 95 (2002). While there are a number of recent written description cases outside the biotechnology context, all of them involve patentees who changed their claims during prosecution to cover a competitor's product. See, e.g., Turbocore Div. of Demag Delaval Turbomachinery Corp. v. Gen. Elec. Co., 264 F.3d 1111 (Fed. Cir. 2001); Hyatt v. Boone, 146 F.3d 1348 (Fed. Cir. 1998); Gentry Gallery, Inc. v. Berkline Corp., 134 F.3d 1473 (Fed. Cir. 1998). See also Janice M. Mueller, Patent Misuse Through the Capture of Industry Standards, 17 BERKELEY TECH. L.J. 623, 639-40 (2002) (distinguishing the biotechnology cases from written description decisions in other areas, especially Union Oil Co. of Cal. v. Atl. Richfield Co., 208 F.3d 989 (Fed. Cir. 2000)). Cf. Matthew L. Goska, Of Omitted Elements and Overreaching Inventions: The Principle of Gentry Gallery Should Not Be Discarded, 29 AIPLA Q.J. 471, 484 (2001) (arguing that the written description requirement makes sense, but that it should not be applied to original claims as it has been in the biotechnology cases).

Other commentators have pointed out that the nonobviousness standard in biotechnology is lower than in other industries. See, e.g., Sara Dastgheib-Vinarov, A Higher Nonobviousness Standard for Gene Patents: Protecting Biomedical Research from the Big Chill, 4 Marq. INTEll. ProP. L. ReV. 143, 154 (2000); John Murray, Note, Owning Genes: Disputes Involving DNA Sequence Patents, 75 CHI.-KENT L. REv. 231, 247 (1999).

121. See, e.g., Gummow v. Snap-On Tools, 58 U.S.P.Q.2d 1414 (N.D. Ill. 2001) (holding that mechanical patents require less disclosure than biotechnology patents due to the uncertainty in biotechnology).

122. Fonar Corp. v. Gen. Elec. Co., 107 F.3d 1543, 1549 (Fed. Cir. 1997). 
Replace software with DNA, though, and the following would result:

As a general rule, where [DNA] constitutes part of a best mode of carrying out an invention, description of such [DNA] is satisfied by a disclosure of the functions of the [DNA]. This is because, normally, [identifying such DNA] is within the skill of the art, not requiring undue experimentation, once its functions have been disclosed.

This is exactly antithetical to the actual rule in biotechnology cases, as stated by Eli Lilly:

A definition by function ... is only an indication of what a gene does, rather than what it is. It is only a definition of a useful result rather than a definition of what achieves that result. Many such genes may achieve that result. The description requirement of the patent statute requires a description of an invention, not an indication of a result that one might achieve if one made that invention. Accordingly, naming a type of material generally known to exist, in the absence of knowledge as to what that material consists of, is not a description of that material. ${ }^{123}$

Conversely, of course, application of the biotechnology rule to software would radically change the law. The legal rules are the same, but the application of those rules to different industries produces results that bear no resemblance to each other. ${ }^{124}$

123. Regents of the Univ. of Calif. v. Eli Lilly \& Co., 119 F.3d 1559, 1568 (Fed. Cir. 1997).

124. Nor are obviousness, disclosure, and patent scope the only doctrines which show such an industry-specific variation. The requirement that an invention have general utility has been all but eliminated in most fields of technology. See Juicy Whip, Inc. v. Orange Bang, Inc., 185 F.3d 1364 (Fed. Cir. 1999) (saying that a patented device is useful if there is a demand for it). However, the requirement is alive and well in the life sciences. The Supreme Court imposed a stringent requirement on pharmaceutical inventions in Brenner v. Manson, 383 U.S. 519 (1966). The Federal Circuit has relaxed that requirement, see In re Brana, 51 F.3d 1560, 1567 (Fed. Cir. 1995), but the court still requires more proof of experimentation in order to satisfy the utility requirement in biotechnology and pharmaceuticals than elsewhere. See U.S. Patent \& Trademark Office, Utility Examination Guidelines, 60 Fed. Reg. 36263 (July 14, 1995) (describing the law as setting different standards for the life sciences); Timothy J. Balts, Substantial Utility, Technology Transfer, and Research Utility: It's Time For a Change, 52 SYRACUSE L. REV. 105 (2002) (describing and criticizing the higher utility standard applied to life sciences); Philippe Ducor, New Drug Discovery Technologies and Patents, 22 RuTGERS COMPUTER \& TECH. 
Polk Wagner has argued that these differences need not concern us greatly, because they are merely case-specific differences rather than systematic variations by industry. ${ }^{125}$ We simply disagree with that reading of the cases. The court's systematic conclusions in different cases, its reliance on industry-specific precedent from case to case, its focus on uncertainty in the biotechnological arts, and its emphasis in biotechnology cases on proof of structure-a discussion totally absent from the software cases-all point in the direction of industry-specific rather than factspecific differences in legal rules.

\section{MODULATING TECHNOLOGY-SPECIFICITY}

Besides divergent results, our survey of the biotechnology and the software patent cases also highlights an important reciprocal relationship between obviousness and disclosure. In biotechnology, where highly detailed disclosure is required to satisfy the enablement and written description standards, similarly detailed disclosure in the prior art is required to render the invention obvious. In software, where little specific detail is needed to satisfy the requirements of disclosure, similarly little detail is needed in the prior art to render the invention obvious. In each case, the Federal Circuit takes the patentability requirements of nonobviousness and disclosure as firmly tied to a common standard. The use and misuse of that common standard, then, is central to the development of technologically tailored patent rules.

\section{A. The Role of the PHOSITA}

The common standard connecting the requirements of obviousness and disclosure is the requirement in each statutory section that obviousness and the sufficiency of disclosure must be considered from the perspective of the "person having ordinary skill in the art," sometimes known by the acronym of PHOSITA. ${ }^{126}$ Much of the case law concerning the PHOSITA

L.J. 369, 431-33 (1996); cf. Rebecca S. Eisenberg \& Robert P. Merges, Opinion Letter As To the Patentability of Certain Inventions Associated With the Identification of Partial cDNA Sequences, 23 AIPLA Q.J. 1 (1995) (arguing that the utility doctrine may bar the patenting of "expressed sequence tags" that can be used to identify human gene sequences).

125. R. Polk Wagner, (Mostly) Against Exceptionalism, working paper (2002). See also Sung, infra note 188 (making the same argument for the biotechnology cases).

126. John O. Tresansky, PHOSITA-The Ubiquitous and Enigmatic Person in Patent Law, 73 J. PAT. \& TRADEMARK OfF. SOC'Y 37 (1991); see also RoberT L. HARMON, PATENTS AND THE FEDERAL CIRCUIT $\S 4.3$ (5th ed. 2001); Joseph P. Meara, Note, Just Who is the Person Having Ordinary Skill in the Art? Patent Law's Mysterious Personage, 77 WASH. L. REV. 267 (2002). The first known use of the term PHOSITA appears to 
arises out of the consideration of the obviousness standard found in $\S 103$ of the patent statute. ${ }^{127}$ Although originally developed as a common law doctrine, the nonobviousness criterion was codified in the 1952 Patent Act as a requirement that the claimed invention taken as a whole not be obvious to one of ordinary skill in the art at the time the invention was made. $^{128}$

The PHOSITA is equally central to calibrating the legal standard for patent disclosure. As the quid pro quo for her period of exclusive rights over an invention, the inventor must fully disclose the invention to the public. The first paragraph of section 112 requires that this disclosure enable "any person skilled in the art" to make and use the claimed invention. ${ }^{129}$ The parallel language suggests that the inventor's compliance with the requirement of enablement should be measured with reference to a standard similar or identical to that in section 103; indeed, the language appears to tie the enablement requirement to nonobviousness via this shared metric. ${ }^{130}$

This same language sets the metric for several related disclosure doctrines as well. First, the definition of enablement affects the patentability requirement of specific utility, as the invention must operate as described in the specification if the inventor is to enable one of ordinary skill to use it. ${ }^{131}$ Additionally, compliance with the independent requirements of adequate written description and best mode disclosure is measured with reference to the understanding of a "person skilled in the art.".132 And finally, the definiteness of patent claims, which must be written so as to warn members of the public just what is and is not covered by the patent, has traditionally been assessed with regard to the knowledge of one having ordinary skill in the art. If the terms of the claims would not be comprehensible to such a person, then they failed the requirements of section $112 .^{133}$

be in Cyril A. Soans, Some Absurd Presumptions in Patent Cases, 10 IDEA 433, 438 (1966).

127. 35 U.S.C. $\S 103(2000)$.

128. Id.

129. 35 U.S.C. $\S 112$ ๆ 1 (2000).

130. The language of the two statutes is not identical, however, and one might draw a distinction between one of ordinary skill and "any person skilled," on the theory that the latter standard includes those with less than ordinary skill. More on this infra Part II.C.

131. See, e.g., Newman v. Quigg, 877 F.2d 1575, 1581-82 (Fed. Cir. 1989).

132. See, e.g., In re Wands, 858 F.2d 731 (Fed. Cir. 1988).

133. The Federal Circuit's recent decision in Exxon Res. \& Eng. Co. v. United States, 265 F.3d 1371, 1376 (Fed. Cir. 2001), however, holds that indefiniteness is a pure question of law. How the court will resolve the understanding of the PHOSITA as a legal mat- 
The PHOSITA is nothing if not versatile, and may also show up as a convenient metric in other unexpected areas, including judicially created patent doctrines. Claim construction requires reference to how the PHOSITA would understand terms in the patent claims. ${ }^{134}$ The PHOSITA reappears in some formulations of the standard for infringement by equivalents. In its germinal opinion on the doctrine of equivalents, Graver Tank, the Supreme Court indicated that the equivalence between elements of an allegedly infringing device and those of a claimed invention might be tested by determining whether the elements were known in the art to be substitutes for one another. ${ }^{135}$ The Federal Circuit strengthened, this use of the PHOSITA by making the "reasonable interchangeability" of elements - judged from the perspective of one of ordinary skill in the art-a fundamental test for equivalence. ${ }^{136}$ A great deal of patent doctrine therefore rests upon the measurement of some legal parameter against the skill and knowledge of the PHOSITA.

This is not to say the PHOSITA has any actual skill or knowledge. Like her cousin, the reasonably prudent person in tort law, ${ }^{137}$ the PHOSITA is something of a juridical doppelganger, ${ }^{138}$ embodying a legal standard for patentability rather than the actual capability of any individual or group of individuals. ${ }^{139}$ Courts have on occasion equated the knowledge of a given individual, such as a patent examiner, with that of the PHOSITA. ${ }^{140}$ But courts walk a fine line between taking the skill of an examiner or other artisan as probative evidence of the level of skill in the art and equating the skill of such persons with the characteristics of the hypo-

ter is not entirely clear, though it undertakes a similar burden in construing patent claims. See Cybor Corp. v. FAS Techs., Inc., 138 F.3d 1448, 1454-55 (Fed. Cir. 1998) (en banc).

134. See Craig Allen Nard, A Theory of Claim Interpretation, 14 HARV. J. L. \& TECH. $1,6(2000)$.

135. See Graver Tank Mfg. Co. v. Linde Air Prods. Co., 339 U.S. 605, 609 (1950).

136. See Hilton Davis Corp. v. Warner-Jenkinson, 62 F.3d 1512, 1519 (Fed. Cir. 1995) (en banc), aff'd in part \& rev'd in part on other grounds, 520 U.S. 17 (1997).

137. See, e.g., Panduit Corp. v. Dennison Mfg. Co. 810 F.2d 1561, 1566 (Fed. Cir. 1987) (comparing the PHOSITA to the "reasonable man" in tort law).

138. Id. (characterizing the PHOSITA as a "ghost").

139. See, e.g., Stewart-Warner Corp. v. City of Pontiac, 767 F.2d 1563, 1570 (Fed. Cir. 1985); Michael H. Davis, Patent Politics, at <http://papers.ssrn.com/sol3/papers. cfm?abstract_id=282056> (visited Nov. 15, 2002) (observing that the PHOSITA standard is "undeniably fictional"); David E. Wigley, Evolution of the Concept of Nonobviousness of the Novel Invention: From a Flash of Genius to the Trilogy, 42 ARIZ. L. REV. 581, 59899 (2000).

140. See Tresansky, supra note 126 , at 58 (collecting cases). 
thetical PHOSITA. ${ }^{141}$ Further, unlike any actual person of skill in the art, the PHOSITA is endowed with knowledge of all of the relevant prior art references. ${ }^{142}$

This places the standard for patentability on a legally objective, rather than subjective, footing. The PHOSITA standard measures the inventor's achievements against a judicially determined external metric, rather than against an expectation based on whatever level of skill the inventor might actually possess. The standard also has the practical effect of avoiding the requirement that judges and other arbiters of patentability be experts in a given field. The PHOSITA standard is thus an ultimate conclusion of law based upon evidence, ${ }^{143}$ not dictated by the capabilities or knowledge of the Patent Office examiner, a reviewing judge, or even that of the inventor:

Realistically, courts never have judged patentability by what the real inventor/applicant/patentee could or would do. Real inventors, as a class, vary in their capacities from ignorant geniuses to Nobel laureates; the courts have always applied a standard based on an imaginary worker of their own devising whom they have equated with the inventor. $^{144}$

The standard is thus objective in the sense that it does not inquire into a particular inventor or artisan's level of skill. But this does not mean that it is static or fixed. Courts consider a number of constituent factors that may be adjusted to modulate the requirements for patentability under different circumstances. The first of these is the definition of the particular "art" in which the PHOSITA is deemed to have ordinary skill. The PHOSITA is generally portrayed as having comprehensive knowledge of the

141. See, e.g., In re Mahurkar Double Lumen Hemodialysis Catheter Patent Litigation, 831 F. Supp. 1354, 1361-62 (N.D. Ill. 1993) (Easterbrook, J., sitting by designation) (taking the finding of the examiner, as a PHOSITA, to be probative of written description compliance).

142. See In re Winslow, 365 F.2d 1017 (C.C.P.A. 1966).

143. See Panduit Corp. v. Dennison Mfg. Co., 810 F.2d 1561 (Fed. Cir. 1987).

144. Kimberly-Clark Corp. v. Johnson \& Johnson, 745 F.2d 1437, 1454 (Fed. Cir. 1984). See also In re Nilssen, 851 F.2d 1401 (Fed. Cir. 1988) (noting that the Board of Patent Appeals and Interferences was not required to have ordinary skill in the art to apply the standard); Hodosh v. Block Drug Co., 786 F.2d 1136 (Fed. Cir. 1986) (stating that actual inventors cannot be required to have the omniscience of the figurative person of ordinary skill). 
references in the particular art. ${ }^{145}$ But the parameters of the art are subject to fluctuation, and thus so is the size and depth of the library of references with which the PHOSITA is presumed to be familiar. For example, in the case of a DNA patent, would the relevant art be biochemistry, or molecular biology, or cell biology, or biology in general? Courts have attempted to avoid drawing such boundaries by defining the PHOSITA's knowledge as that reasonably pertinent to the problem the inventor was trying to solve. But this requires that the court engage in the equally mercurial exercise of defining the problem that the inventor had under consideration. ${ }^{146}$

A second PHOSITA variable that may be adjusted to different circumstances is the level of skill that would be considered "ordinary." Unlike the inventor, who almost by definition is presumed to be one of extraordinary skill, ${ }^{147}$ the PHOSITA standard contemplates some median or common level of skill. In assessing that common level, courts may take into account a long list of factors, including the approaches found in the prior art, the sophistication of the technology involved, the rapidity of innovation in that field, and the level of education typical of those in the field. ${ }^{148}$ The courts have also endowed the PHOSITA with mediocre personality traits; she is conceived of as an entity that adopts conventional approaches to problem solving, and is not inclined to innovate, either via exceptional insight or painstaking labor. ${ }^{149}$

Some care must be exercised in characterizing the PHOSITA, as it is tempting to do so on the basis of an unfounded presumption, which is that the PHOSITA remains constant from section to section of the patent statute. On the contrary, some commentators have recognized the possibility that the imaginary artisan found in these different statutory sections, though bearing the same denomination, might well display different and even inconsistent characteristics as between the different sections. ${ }^{150}$ The PHOSITA for purposes of obviousness may not necessarily be the PHOSITA for purposes of enablement, written description, definiteness, or equivalence. Because she is a legal construct designated to embody certain

145. Although, as we point out below, this imputed knowledge varies a bit depending upon whether obviousness or disclosure is at issue. See infra notes 150-55.

146. See e.g., George J. Meyer Mfg. Co. v. San Marino Elec. Corp., 422 F.2d 1285, 1288 (9th Cir. 1970) (deeming the PHOSITA in optical bottle inspection art to be aware of prior art in optical missile tracking field).

147. Standard Oil Co. v. Am. Cyanamid Co., 774 F.2d 448, 454 (Fed. Cir. 1985).

148. See, e.g., Bausch \& Lomb Inc. v. Barnes-Hind, Inc., 796 F.2d 443 (Fed. Cir. 1986) (listing pertinent factors); see also Helifix Ltd. v. Blok-Lok Ltd., 208 F.3d 1339 (Fed. Cir. 2000) (stating that district court erred by failing to consider these factors).

149. Am. Cyanamid Co., 774 F.2d at 454.

150. See Tresansky, supra note 126 , at 52-53. 
legal standards, the PHOSITA could well change depending on the purpose she is serving at the time. Understanding this difference is critical, because the Federal Circuit's linkage of obviousness and enablement depends on the easy equation of the PHOSITAs.

Some disparity of this sort does in fact appear in the judicial characterization of the PHOSITA in the contexts of obviousness and of enablement. The section 103 PHOSITA appears to be something of a problem solver, who the courts set to work hypothetically tackling the problem solved by the inventor. ${ }^{151}$ To be sure, the obviousness PHOSITA is not an especially inspired problem solver, as she is imagined to remain stuck in the rut of conventional thinking. ${ }^{152}$ But the obviousness PHOSITA is still someone who is trying to solve new problems. By contrast, the PHOSITA of the first paragraph of section 112 shows no such innovative tendency, but is simply a user of the technology. If the enablement PHOSITA shows any problem solving ability, it is in tapping the prior art to fill in gaps left by the inventor's disclosure - a rather different skill than that of the obviousness PHOSITA. ${ }^{153}$

The two PHOSITAs also differ in the date at which knowledge is imputed to them. The knowledge of the obviousness PHOSITA is assessed as of the time of invention, while the enablement PHOSITA is aware of information available at the time a patent is filed. Due to the passage of time, the latter universe of references is likely to be larger. The temporal disparity is even stronger when the doctrine of equivalents PHOSITA is employed; this latter entity knows of all developments up to the date of infringement. ${ }^{154}$ But conversely, hidden or nonpublic references which may serve as prior art under section 103 are not necessarily imputed to the knowledge of the PHOSITAs who make or use the invention under section 112 , as such references are not readily available to the public. ${ }^{155}$

\section{B. Misapplication of the PHOSITA Standard}

The PHOSITA approach in general represents the proper standard for patent law. Basing the proof required on the level of skill in the art makes

151. See Orthopedic Equip. Co. v. United States, 702 F.2d 1005 (Fed. Cir. 1983); In re Grout, 377 F.2d 1019 (C.C.P.A. 1967).

152. Am. Cyanamid Co., 774 F.2d at 448.

153. See Tresansky, supra note 126 , at 54.

154. See Warner-Jenkinson Co., Inc. v. Hilton Davis Chem. Co., 520 U.S. 17, 37 (1997) (holding that equivalence is tested at the time of infringement). Indeed, were it otherwise, the doctrine of equivalents could not feasibly be applied to later-developed technologies.

155. See Quaker City Gear Works, Inc. v. Skil Corp., 747 F.2d 1446 (Fed. Cir. 1984); In re Howarth, 654 F.2d 103 (C.C.P.A. 1981). 
logical sense. ${ }^{156}$ At the simplest level, this approach is intended to benefit the public; people who work in a given technology must understand the patent as it relates to the prior art, so it makes sense to take into account what that person knows in order to decide whether a patent is obvious or has been enabled. From a policy standpoint, the practicality of working in different technologies requires a flexible approach to determining disclosure or obviousness, and the PHOSITA approach gives a court that flexibility. In this sense, patent law is inherently technology-specific, in essence offering different and fact-sensitive standards of disclosure and obviousness for different technologies.

But even recognizing that the PHOSITA standard dictates that different technologies will be accommodated in different ways, the developments that we have described in software and biotechnology seem to us extraordinary and difficult to explain solely by reference to the level of skill in these arts. Consider, for example, the extremely stringent disclosure standard developed in the biotechnology cases. If the PHOSITA analysis explains that requirement, it suggests that the Federal Circuit believes that biotechnology researchers need a very high degree of assurance before they are capable of replicating an invention. Computer programmers, on the other hand, apparently require very little assurance - simply an indication of function will do. Similarly, with regard to obviousness, the court appears to believe that computer programmers can fully envision working code from only a suggestion of function, whereas biotechnologists apparently need genetic sequences explicitly spelled out in the prior art to render a molecule obvious. As detailed below, we are not persuaded that the levels of skill in these arts are in fact so different, either for innovators or for users.

In this section, we seek to understand why the Federal Circuit's application of the PHOSITA standard has produced such incongruous results in the industries we studied. In order to identify the source of the anomalies in biotechnology and software, we look first to the Federal Circuit's application of this standard, rather than to the standard itself. One possibility, which has occurred to previous commentators as well as to us, is that the Federal Circuit application of the PHOSITA standard in these technologies is wrong as a matter of science. ${ }^{157}$ One reading of these cases is that the Federal Circuit seems to have substituted caricature for a nuanced understanding of the technology. The court has repeatedly suggested that

156. But see Davis, supra note 139 , at 32 (use of PHOSITA is "disingenuous and almost foolish").

157. See, e.g., Varma \& Abraham, supra note 104; Rai, Addressing New Technology, supra note 104; Rai, Patent Gold Rush, supra note 104. 
programming itself is a "mere clerical function" that presumably does not warrant the grant of a patent. The court seems to consider only the ideas or functions of a computer program worthy of patent protection. In short, the court thinks of programmers as people of astonishing skill, capable of implementing any idea in a computer program as a matter of course. Sometimes this assumption benefits patentees, notably in enablement and best mode determinations. ${ }^{158}$ Other times, such as in obviousness cases, the assumption that programmers are extremely skilled works against the patentee. ${ }^{159}$ But as a matter of computer science, there is ample evidence that the court's assumptions are contrary to actual practice. Those who actually work in the industry know that coming up with an idea for a computer program is rather less than half the battle. ${ }^{60}$ Programs can take years to write even under the best circumstances. Some will simply not work. Others will require innovative programming techniques. Even once they are written, most programs have bugs that must be worked out in order for the program to be stable. ${ }^{161}$ In many cases, the process of writing the program changes the idea itself in a sort of iterative feedback loop. ${ }^{162}$ Not only is it wrong to say that writing a program is a "mere clerical function" to a skilled programmer, but in fact many of the truly innovative improvements in computer software occur at the level of programming, not in the idea to have a computer perform a specific function. ${ }^{163}$

In the biotechnology cases, the situation is reversed; the court focuses repeatedly on the "uncertainty" inherent in the field, scoffing at claims

158. See supra notes 28-36 and accompanying text (noting the low standards applied to software patents under $\S 112$ ).

159. See supra notes $43-46$ and accompanying text.

160. See, e.g., Computer Assoc. v. Altai, Inc., 982 F.3d 693 (2d Cir. 1992). See also 4 Nimmer on Copyright §13.03[F]; Peter S. Menell, An Analysis of the Scope of Copyright Protection for Application Programs, 41 STAN. L. REV. 1045 (1989); Pamela Samuelson et al., A Manifesto Concerning the Legal Protection of Computer Programs, 94 ColUM. L. REV. 2308 (1994); Thomas M. Gage, Note, Whelan Assoc. v. Jaslow Dental Laboratories: Copyright Protection for Computer Software Structure-What's the Purpose?, 1987 WISC. L. REV. 859. Cf. Mark A. Lemley \& David W. O'Brien, Encouraging Software Reuse, 49 STAN. L. REV. 255, 261-66 (1997) (detailing the cost savings available from reusing computer code rather than reinventing it from scratch).

161. See Lemley \& O'Brien, supra note 160, at 261-64 and sources cited therein.

162. See, e.g., Menell, supra note 6.

163. See Lemley \& O'Brien, supra note 160 , at 302 (encouraging protection for such ideas in preference to the more common patents on old ideas implemented in digital format). Indeed, Richard Stern and Julie Cohen have both proposed that software patents be limited to innovative programs rather than simply the concept of implementing a particular function using a computer. See also Cohen, supra note 58, at 1169; Richard H. Stern, Tales From the Algorithm War: Benson to Iwahashi, It's Déjà vu All Over Again, 18 AIPLA Q.J. 371, 395 (1991). 
drawn to molecular function rather than structure and demanding precise disclosure of any embodiment. ${ }^{164}$ The court seems to believe that biotechnology is as much a black art as a science, where the result of experimentation is largely out of the skilled artisan's hands. While the assumption that an art is uncertain may befit a new and undeveloped field, the court has maintained its assumption that biotechnology is an uncertain art long after the industry began to mature. The Federal Circuit has sidestepped the difficulty of determining the level of skill in the art in each case by grounding biotechnology patent standards in a doctrine of structural foreseeability. This solution is attractive to the court, as the requirement of foreseeable structure becomes an axiom from which other patent standards can be neatly derived. However, just as we are cautioned by the old maxim that when one has a hammer everything looks like a nail, it would seem that the Federal Circuit, having once crafted a solution based on structural foreseeability, begins to see every biotechnology patenting problem as a problem of structure. In Bell and Deuel the court's belief in uncertainty benefits the patentee, since it means that knowledge of a protein and a method for deriving the cDNA sequence did not render the cDNA sequence obvious without the disclosure of structure. ${ }^{165}$ By contrast, the same assumption about uncertainty hurts patentees in cases like Enzo, Lilly and Amgen, because it precludes them from claiming any DNA sequence they have not actually described in structural terms in the patent specification. ${ }^{166}$ All of these holdings are based on the assumption that one ordinarily skilled in biotechnology cannot move conceptually from a protein to a DNA sequence, or from the DNA sequence of one organism to the corresponding DNA sequence of another organism.

Arguably this understanding of the science of biotechnology is simply wrong. Robert Hodges has argued that "[T]he key event is the cloning of the first gene in a family of corresponding genes. Once a researcher accomplishes this very difficult task, the researcher can typically obtain

164. See supra notes 115-118 and accompanying text (discussing the role of uncertainty in the Federal Circuit's biotechnology jurisprudence).

165. See In re Deuel, 51 F.3d 1552, 1559 (Fed. Cir. 1995); In re Bell, 991 F.2d 781 (Fed. Cir. 1993).. Cf. Fiers v. Revel, 984 F.2d 1164 (Fed. Cir. 1993) (using the same standard in an interference proceeding to benefit one applicant at the expense of another). But cf. In re Mayne, 104 F.3d 1339 (Fed. Cir. 1997) (DNA sequence in prior art rendered obvious a claim to an altered version of that sequence that changed only one amino acid).

166. See Enzo Biochem v. Calgene, Inc., 188 F.3d 1362, 1371 (Fed. Cir. 1999); Regents of the Univ. of California v. Eli Lilly \& Co., 119 F.3d 1559 (Fed. Cir. 1997); In re Goodman, 11 F.3d 1046, 1052 (Fed. Cir. 1993); Amgen, Inc. v. Chugai Pharmaceutical Co., 927 F.2d 1200 (Fed. Cir. 1991). 
other members of the gene family with much less effort." ${ }^{167}$ Indeed, today the process is largely automated. Such research is properly compared to searching a "black box" in which are contained molecules of known characteristics, if unknown structure; the search is conducted on the basis of what is known-the function-rather than on the basis of what is unknown - the precise structure. The function of the molecule that will be found is predictable, as is the likelihood of finding such a molecule, even if the precise structure of the molecule cannot be predicted. ${ }^{168}$

This explanation of the Federal Circuit's jurisprudence in these areas is not altogether satisfactory, as (in biotechnology, at least) it fails to explain the court's indifference to the technology subsequent to Amgen. ${ }^{169}$ The obviousness decision in Amgen clearly rested upon the uncertain likelihood of success in the particular probing methodology used to find the EPO gene. Had the court adhered to this analysis in later cases, carrying forward into subsequent opinions a static impression of biotechnological techniques, the poor fit between patent doctrine and patent policy could be easily explained; indeed some commentators have offered this easy explanation. ${ }^{170}$ But in those later cases, the court seems quite indifferent to the certainty or uncertainty of methodological success, fashioning instead a standard based on structural precision and foreseeability that ignores the state of technology, past or present. It seems not so much that the court misunderstood the changes in technology since Amgen as that the court simply ignored them.

This observation might be accommodated by an alternative explanation: that the court, rather than stumbling in its application of law to changing technology, is as a matter of law deliberately creating a unique enclave of patent doctrine for biotechnology, making patent law indeed

167. Robert A. Hodges, Black Box Biotech Inventions: When a Mere "Wish or Plan" Should be Considered an Adequate Description of the Invention, 17 GA. ST. U. L. REV. 831,832 (2001). See also John M. Lucas, The Doctrine of Simultaneous Conception and Reduction to Practice in Biotechnology: A Double Standard for the Double Helix, 26 AIPLA Q.J. 381, 418 (1998) ("Making the inventions of Amgen, Fiers and Lilly today would be routine.").

168. See, e.g., Alison E. Cantor, Using the Written Description and Enablement Requirements to Limit Biotechnology Patents, 14 HARV. J. L. \& TECH. 267, 310-11 (2000) (stating that " $[\mathrm{t}]$ here is already indication that initial biotechnology techniques are increasingly considered to be more predictable and are more likely to fall into the category of routine experimentation" and citing monoclonal antibodies as an example).

169. See supra notes 106-109 and accompanying text.

170. See supra notes $111-113$ and accompanying text. 
technology-specific. ${ }^{171}$ The same explanation might be applied to the software cases: it is not a unique set of facts applied to the PHOSITA construct that is generating a technology-specific body of patent law, but rather a deliberate manipulation of doctrine itself. ${ }^{172}$ Yet this alternative explanation seems to us even less satisfactory than the first. It essentially moves the problem up one level of abstraction to argue that the Federal Circuit is not mistaken as a matter of fact about the state of technology in biotechnology and software, but rather mistaken as a matter of policy about the needs of those industries. If the court is taking the trouble of fashioning individual patentability standards for different areas of subject matter, one would expect that the standards fashioned would be suited to the needs of the different areas addressed.

Yet the literature analyzing these industries suggests that the likely results of the Federal Circuit's software and biotechnology cases are illconsidered as a policy matter. Several commentators have examined the undesirable consequences of creating an anticommons of fragmented property rights in the biotechnology industry. ${ }^{173} \mathrm{~A}$ multitude of narrow patents seems likely to strangle downstream product development in a mo-

171. Polk Wagner suggests a third possible explanation: that one judge, Judge Lourie, wrote almost all of the biotechnology cases, and that those decisions reflect not the court's consistency but one author's consistency. See Wagner, supra note 125, at 4, $5 \mathrm{n}$. 15. We think this is a distinction without a difference. The Federal Circuit has chosen to assign to Judge Lourie responsibility for writing virtually all of its biotechnology cases. Many other judges have joined his opinions. If one judge writes all of the opinions in a particular area, over time it is reasonable to assume that he speaks for the court. If Wagner is right, one possible difference is that it may be easier for the Federal Circuit to change its behavior merely by changing who writes opinions.

172. Cf. Craig Allen Nard, Toward a Cautious Approach to Obeisance: The Role of Scholarship in Federal Circuit Patent Law Jurisprudence, 39 HouSTON L. REV. 667 (2002) (arguing that the Federal Circuit has been less than candid about its technologyspecific decisions). Judge Gajarsa has expressly acknowledged this problem: "We also need to determine whether or not we should have a different standard of patentability for biotech cases and also for software. Should there be a different patentability standard that is established by decision of our court or by statute? This is an issue which needs to be considered and thoughtfully analyzed." Hon. Arthur J. Gajarsa, Quo Vadis?, 6 MARQ. INTELL. PROP. REV. 1, 6-7 (2002).

173. See Michael A. Heller \& Rebecca S. Eisenberg, Can Patents Deter Innovation? The Anticommons in Biomedical Research, 280 SCI, at 698, 698 (1998) (patenting genetic research can lead to an "anticommons" in which multiple, conflicting property rights impede efficient use of the patents); see also Rebecca S. Eisenberg, A Technology Policy Perspective on the NIH Gene Patenting Controversy, 55 U. PITT. L. REV. 633 (1994); Arti K. Rai, Fostering Cumulative Innovation in the Biopharmaceutical Industry: The Role of Patents and Antitrust, 16 BERKELEY TECH. L.J. 813 (2001); Arti K. Rai, The Information Revolution Reaches Pharmaceuticals: Balancing Innovation Incentives, Cost, and Access in the Post-Genomics Era, 2001 U. ILL. L. REV. 173. 
rass of required licenses, yet the combination of stringent disclosure and permissive obviousness standards is likely to produce just such a patent configuration. In contrast, other commentators have worried over the deleterious effects of overbroad patents on the incremental development of short-lived software products. ${ }^{174}$ Again, the Federal Circuit's combination of permissive disclosure and stringent obviousness for software inventions seems likely to produce exactly the results commentators have feared. In each case, application of the PHOSITA standard has lead to an industryspecific outcome that seems exactly the wrong one for the particular industry. ${ }^{175}$

\section{Obstacles to Applying the PHOSITA Standard Properly}

If, as we suggest, the concept of the PHOSITA makes sense, why has the Federal Circuit got it wrong in these industries? There are several reasons. First, we think that there are several structural barriers that make it difficult for courts to accurately assess the level of skill in a complex technological art. As a practical matter, it is worth emphasizing that judges are at a rather serious disadvantage in trying to put themselves in the shoes of an ordinarily skilled scientist. Judges generally don't have any scientific background and, at the district court level at least, most law clerks don't either. Further, district court judges have extremely full dockets with many different types of cases. The average judge may hear no more than one patent case every few years. ${ }^{176}$ Few of those will be software or biotech-

174. See, e.g., Pamela Samuelson et al., A Manifesto Concerning the Legal Protection of Computer Programs, 94 COLuM. L. REV. 2308, 2345-46 (1994); Cohen \& Lemley, supra note 16.

175. This short summary of the problem cannot of course fully address the issue; we discuss it in more detail in our subsequent work. See Burk \& Lemley, supra note 5.

176. There are roughly 1700 patent cases filed per year. The exact data for the years 1995-1999 can be found in the Derwent Litalert database at <http://www.derwent. com/intellectualproperty/litalert.html $>$. The data that follow were compiled as of June 1 , 2000 , and involve cases labeled "patent."

$\begin{array}{cc}\text { Year } & \text { Number of Cases Filed } \\ 1999 & 1,652 \\ 1998 & 1,730 \\ 1997 & 1,731 \\ 1996 & 1,514 \\ 1995 & 1,258\end{array}$

Id.

Most of these cases settle, however. Kimberly Moore's comprehensive study of all patent cases that went to trial found only 1,411 cases in the 17 years from 1983 to 1999, an average of less than 100 cases per year. Kimberly A. Moore, Judges, Juries, and Patent Cases-An Empirical Peek Inside the Black Box, 99 MicH. L. REV. 365, 380 (2000). Since there are over 600 district court judges in the United States, it is obvious 
nology cases. ${ }^{177} \mathrm{~A}$ very busy judge must therefore learn not only patent law but also some difficult science in a very short period of time. Expert witnesses can help, but the Federal Circuit has imposed some limits on the extent to which district courts can rely on such evidence. ${ }^{178}$ In particular, courts must avoid the temptation to assume that the expert witness is a person ordinarily skilled in the art. ${ }^{179}$ Even the Federal Circuit, which does not suffer nearly so much from these limitations, ${ }^{180}$ is not in a position to fully understand all of the science it encounters. ${ }^{181}$ Given these limitations, courts understandably won't get it right all the time. ${ }^{182}$

that most judges get only a few filed patent cases a year, and well less than one patent trial a year. In fact, many judges get even fewer cases than this number would suggest (though others get more), since the concentration of innovation in certain regions and the permissibility of forum shopping in patent cases cause patent cases to be bunched in a few districts. See Kimberly A. Moore, Forum Shopping in Patent Cases: Does Geographic Choice Affect Innovation?, 79 N.C. L. REV. 889 (2001) (analyzing where patent suits are filed).

177. See John R. Allison \& Mark A. Lemley, Empirical Evidence on the Validity of Litigated Patents, 26 AlPLA Q.J. 185, 217 tbl.5 (1998) (demonstrating that between 1989 and 1996 , only $3 \%$ of patent cases litigated to judgment involved biotechnology and only $1 \%$ involved software).

178. See Vitronics Corp. v. Conceptronic, Inc., 90 F.3d 1576, 1584 (Fed. Cir. 1996) (stating that courts may rely on expert testimony in construing patent claims only in rare circumstances); but see Pitney-Bowes v. Hewlett-Packard Corp., 182 F.3d 1298, 1308 (Fed. Cir. 1999) (holding that judges may hear expert testimony on the meaning of patent claims, but may not normally rely on such testimony). This distinction between admitting testimony to help the judge understand the claims and reliance on such testimony may make conceptual sense, but courts reading this line of cases may be reluctant to hear such evidence at all. Plus, it will not help much in deciding pretrial motions.

179. See, e.g., Dayco Prods. v. Total Containment, Inc., 258 F.3d 1317, 1324 (Fed. Cir. 2001) ("Our objective is to interpret the claims from the perspective of one of ordinary skill in the art, not from the viewpoint of counsel or expert witnesses."); Endress \& Hauser v. Hawk Measurement Sys., 122 F.3d 1040, 1042 (Fed. Cir. 1997) (implying that experts need not themselves be of ordinary skill in the art: "The 'person of ordinary skill' in the art is a theoretical construct" used in determining obviousness under $\S 103$, "and is not descriptive of some particular individual.").

180. While relatively few Federal Circuit judges have technology backgrounds, John R. Allison \& Mark A. Lemley, How Federal Circuit Judges Vote in Patent Validity Cases, 27 FLA. ST. U. L. REV. 745, 751 n.23 (2000), many of their clerks do. Further, the Federal Circuit has more time to consider each case, has the full record before it, and gets many more patent cases, including software and biotechnology cases, than any district court judge would.

181. Arti Rai argues that the Federal Circuit should defer to the PTO, because the PTO better understands biotechnology. Rai, Patent Gold Rush, supra note 104. We agree with her that the Federal Circuit makes mistakes in this area. We are not persuaded that the PTO can do any better, however, particularly given the minimal time examiners can spend on any one invention. See Mark A. Lemley, Rational Ignorance at the Patent Of- 
Second, the timing of the PHOSITA analysis complicates the court's task. While the court will determine the level of skill in the art during a pretrial hearing or at trial, the appropriate level of skill in the art is not what people know at the time of trial, but what people knew at the time of the invention (in the case of obviousness) or the filing of a patent application (in the case of enablement). ${ }^{183}$ On average, it takes more than twelve years from the time a patent application is filed until final judgment on the merits; it takes even longer from the date of invention, of course. ${ }^{184}$ So courts trying to determine the level of skill in the art must learn not just science, but the history of that science. Courts and expert witnesses must shut out of their minds intervening developments in the field. This is notoriously hard to do. Empirical evidence has demonstrated that people in general, and judges in particular, are subject to a "hindsight" bias: they are likely to reason backwards from what did happen to make assumptions about what was likely to happen ex ante. ${ }^{185}$ The Federal Circuit has repeatedly recognized the problem of hindsight bias in its obviousness juris-

fice, 75 Nw. U. L. REV. 1495, 1500 (2001) (noting that examiners spend only eighteen hours per application on average).

182. Cf. Stephen L. Carter, Custom, Adjudication, and Petrushevsky's Watch: Some Notes From the Intellectual Property Front, 78 VA. L. REV. 129, 132 (1992) (worrying that judges may not be particularly good at "judicial anthropology").

183. See Arkie Lures, Inc. v. Gene Larew Tackle, Inc., 119 F.3d 953, 956 (Fed. Cir. 1997) (holding that PHOSITA analysis must "focus on conditions as they existed when the invention was made" in obviousness cases).

184. Allison \& Lemley, Empirical Evidence, supra note 177, at 236 tbl.11 (12.3 years on average). This has been a particular problem in biotechnology cases, particularly because they spend longer in prosecution and because biotechnology patents are often most valuable at the end of their lives. See, e.g., Enzo Biochem v. Calgene, Inc., 188 F.3d 1362, 1371 (Fed. Cir. 1999) (16 year-old invention); Genentech, Inc. v. Novo Nordisk, 108 F.3d 1361, 1367 (Fed. Cir. 1997) (18 year-old invention); Jeffrey S. Dillen, DNA Patentability-Anything But Obvious, 1997 WISC. L. REV. 1023, 1038 (noting this time lag).

185. There is an interesting empirical literature in the behavioral law and economics movement on hindsight bias. The existence of such a bias is well documented. In the behavioral science literature, see, e.g., Baruch Fischhoff, Hindsight $\neq$ Foresight: The Effect of Outcome Knowledge on Judgment Under Uncertainty, 1 J. EXPERIMENTAL PSYCHOL.: Hum. Perception \& Performance 288 (1975); Amos Tversky \& Daniel Kahneman, Availability: A Heuristic for Judging Frequency and Probability, 5 COGNITIVE Psych. 207 (1973). In the legal literature, see, e.g., BEHAVIORAL LAW AND ECONOMICS (Cass Sunstein ed. 2000); Russell Korobkin \& Thomas S. Ulen, Law and Behavioral Science: Removing the Rationality Assumption from Law and Economics, 88 CALIF. L. REV. 1051, 1095 (2000); Eric Talley, Disclosure Norms, 149 U. PA. L. REV. 1955, 2000 (2001). There is even empirical evidence that federal judges are subject to hindsight bias. See Chris Guthrie et al., Inside the Judicial Mind, 86 CORNELL L. REV. 777, 799-805 (2001). 
prudence, ${ }^{186}$ and has built rules designed to cope with it there, ${ }^{187}$ but hindsight bias risks infecting the PHOSITA analysis in enablement and claim scope as well. Hindsight bias will normally lead factfinders to overestimate the level of skill in the art, since subsequent advances will suggest that the invention could not have been that difficult to do. This effect is likely to be the most pronounced in technologies that are familiar or readily understood by the trier of fact - that is, in the "predictable" arts. Occasionally, however, hindsight bias may have the opposite effect, notably where certain things known or believed at one time to be feasible turn out later to be more difficult than anticipated. ${ }^{188}$

Finally, the backward-looking nature of the legal system itself creates a problem that is in some sense the opposite of the hindsight bias. Legal rules are based on stare decisis. The law accumulates nuance over time by respecting and building on the body of existing precedent. Only rarely will courts expressly reject their prior decisions. This system has worked well over time in producing thoughtful legal rules. ${ }^{189}$ Judges trained in this process will naturally tend to apply it to factual issues they see repeatedly. Indeed, doing so seems economical as well, since revisiting those factual determinations appears redundant. Thus, once the Federal Circuit has ruled on the level of skill in a particular art, the temptation is strong for both that court and district courts to apply that determination in subsequent cases. This tendency is evident in both software and biotechnology cases. In the software cases, the court in Northern Telecom held that the patentee need not disclose the actual code implementing a program in or-

186. See, e.g., Al-Site Corp. v. VSI Int'l, Inc., 174 F.3d 1308, 1324 (Fed. Cir. 1999); Monarch Knitting Mach. Corp. v. Fukuhara Indus. \& Trading Co., 139 F.3d 877 (Fed. Cir. 1998).

187. See, e.g., In re Dembiczak, 175 F.3d 994, 999 (Fed. Cir. 1999) ("Our case law makes clear that the best defense against the subtle but powerful attraction of a hindsightbased obviousness analysis is rigorous application of the requirement for a showing of the teaching or motivation to combine prior art references."). Indeed, the Federal Circuit may have overcompensated, making it very difficult to combine references in order to prove obviousness. See Lemley \& O'Brien, supra note 160, at 301 (making this argument). For an extremely strict statement of the legal standard on combining references, see Winner Int'l Royalty Corp. v. Wang, 202 F.3d 1340 (Fed. Cir. 2000).

188. For a detailed discussion of hindsight in biotechnology cases, see Lawrence $M$. Sung, On Treating Past as Prologue, 2001 U. ILL. J. L. TECH. \& POL'Y 75.

189. For arguments suggesting the common law evolves towards efficiency over time, see RICHARD A. POSNER, ECONOMIC ANALYSIS OF LAW 23-27 (1st ed. 1979); George L. Priest, The Common Law Process and the Selection of Efficient Rules, 6 J. LEGAL STUD. 65 (1977); Paul H. Rubin, Why is the Common Law Efficient?, 6 J. LEGAL STUD. 51 (1977). Whether or not this controversial claim is correct, stare decisis is clearly entrenched in the legal mindset. 
der to satisfy the enablement or best mode requirements. ${ }^{190}$ The court in that case acknowledged that determinations of the level of skill in the computer industry should be made on a case-by-case basis ${ }^{191}$; but subsequent Federal Circuit decisions have not inquired separately into the level of skill in the art, or explored the complexity of the program before them in much detail. Instead, they have tended to rely on prior cases holding that code need not be disclosed.

In biotechnology the linkage is even stronger. In re Bell concluded that knowledge of an amino acid sequence produced by a gene, coupled with a plan for identifying the DNA sequence of the gene, did not render the DNA sequence itself obvious. ${ }^{192}$ In re Deuel relied on Bell's conclusion, despite the fact that biotechnology had advanced somewhat between the two inventions. ${ }^{193}$ In Regents of the University of California v. Eli Lilly \& Co. ${ }^{194}$ the court expressly relied on its conclusions about the level of skill in the art in Bell and Deuel to determine its conclusions regarding written description. ${ }^{195}$ Fiers is even more explicit in this regard, creating a firm

190. N. Telecom, Inc. v. Datapoint Corp., 908 F.2d 931, 941 (Fed. Cir. 1990).

191. Id. at 941 .

192. In re Bell, 991 F.2d 781, 785 (Fed. Cir. 1993).

193. In re Deuel, 51 F.3d 1552, 1559 (Fed. Cir. 1995). In Bell, the prior art disclosed the amino acid sequence for the proteins of interest, and a method for cloning genes. By contrast, the art in Deuel disclosed only a partial sequence. Nonetheless, the passage of several years between the priority dates of the applications (Deuel's application was first filed January 8, 1990, and Bell's application was filed June 16, 1987) was ignored by the court, which did not focus on or even mention when the inventions occurred.

194. 119 F.3d 1559 (Fed. Cir. 1997).

195. According to the court:

Example 6 provides the amino acid sequence of the human insulin A and $\mathrm{B}$ chains, but that disclosure also fails to describe the cDNA. Recently, we held that a description which renders obvious a claimed invention is not sufficient to satisfy the written description requirement of that invention. Lockwood, 107 F.3d at 1572 . We had previously held that a claim to a specific DNA is not made obvious by mere knowledge of a desired protein sequence and methods for generating the DNA that encodes that protein. See, e.g., In re Deuel, 51 F.3d 1552, 1558, 34 USPQ2d 1210, 1215 (1995) ("A prior art disclosure of the amino acid sequence of a protein does not necessarily render particular DNA molecules encoding the protein obvious because the redundancy of the genetic code permits one to hypothesize an enormous number of DNA sequences coding for the protein."); In re Bell, 991 F.2d 781, 785, 26 USPQ2d 1529, 1532 (Fed.Cir. 1993). Thus, a fortiori, a description that does not render a claimed invention obvious does not sufficiently describe that invention for purposes of $\S 112$ ๆ 1 . Because the ' 525 specification provides only a general method of producing human insulin cDNA and a description of the human insulin A and B chain amino 
rule that conception of a DNA sequence requires a listing of that sequence "irrespective of the complexity or simplicity of the method of isolation." 196

While apparently logical, the reliance on industry-specific precedent in determining the level of skill in the art is problematic. First, while both obviousness and enablement rely on the PHOSITA construct, the PHOSITA is not necessarily the same for obviousness and enablement even in a single case. Obviousness is tested at the time the invention was made, while enablement is tested at the time the application was filed. Clearly the application cannot be filed until after the date of invention, and in some cases several years elapse between the two. ${ }^{197}$ Knowledge in the art can change during this period, sometimes dramatically. Second, and more important, the level of skill in the art will normally change between the dates of different inventions. It is hazardous, therefore, to rely on one court's statement of the level of skill in the art as determinative or even evidentiary of the level of skill in the same art at a different time. The level of skill in the art is a factual question that must be determined anew on the particulars of each case. ${ }^{198}$

A related problem is the equally time-honored tradition of reasoning by analogy. If courts and lawyers can't find precedent directly on point, they will turn to the closest available analog. In the case of biotechnology, the court appears to have taken its understanding of DNA directly from its small-molecule chemistry cases of a generation before. But if reliance on precedent is bad in the case of the PHOSITA, reliance on analogy is worse. Expanding the search for the PHOSITA beyond a narrow definition of the field in question will almost certainly get it wrong, as indeed the court has done in the biotechnology cases. Given the fact-specific nature of the inquiry, the Federal Circuit may need to resist its tendency-well documented in other areas- to substitute its factual conclusions for those

acid sequences that cDNA encodes, it does not provide a written description of human insulin cDNA.

\section{Id. at 1567.}

196. Fiers v. Revel, 984 F.2d 1164, 1169 (Fed. Cir. 1993).

197. The law permits a one-year grace period between any public act and the filing of a patent application. See 35 U.S.C. $§ 102$ (b) (2000). But many inventors wait even longer between invention and the filing of an application. This is permissible, so long as they do not put the invention on sale or in public use in the interim, and do not abandon it. 35 U.S.C. § 102(c) (2000).

198. For a detailed discussion, see Dillen, supra note 184, at 1039-44. The U.S. Court of Customs and Patent Appeals in In re Driscoll, 562 F.2d 1245, 1250 (C.C.P.A. 1977), and the Federal Circuit in Enzo Biochem. v. Calgene, Inc., 188 F.3d 1362, 1374 n.10 (Fed. Cir. 1999), both recognized this. However, it has proven a hard rule to adhere to. 
of the district court. ${ }^{199}$ A clear signal by the Federal Circuit that identifying the PHOSITA is a fact-specific question that must be decided anew in each case (perhaps by reference to expert testimony) might go a long way towards solving the problem of substituting precedent and analogy for detailed analysis. ${ }^{200}$ Courts should also spend more time and effort fleshing out the PHOSITA, who in many opinions seems to be mentioned only perfunctorily. ${ }^{201}$

\section{FIXING THE PHOSITA DOCTRINE}

If we are right that patent law is technology-specific because of the reliance on the PHOSITA, and that the Federal Circuit's application of that standard has proven problematic in biotechnology and software cases, what is to be done? We have suggested that industry-specific tailoring is desirable, but the reciprocal relationship between obviousness and disclosure, mediated by a common PHOSITA standard, leads to perverse results. Consequently, in this section, we propose that courts "decouple" the PHOSITA standards for obviousness and enablement, thus allowing the two requirements for patentability to be independently adapted to the incentive requirements of various technologies.

The seeds of such an approach may already be latent in established legal doctrines of obviousness and enablement. Recall that the characteristics of the obviousness PHOSITA and those of the enablement PHOSITA are not entirely coterminous; they are measured at different times. Because the level of knowledge for the enablement PHOSITA is measured at the

199. See, e.g., William C. Rooklidge \& Matthew F. Weil, Judicial Hyperactivity: The Federal Circuit's Discomfort With Its Appellate Role, 15 BERKELEY TECH. L.J. 725 (2000) (noting this problem); Arti K. Rai, Facts, Law and Policy: An Allocation-ofPowers Approach to Patent System Reform, _ CoLUM. L. REV. _ (forthcoming 2003) (arguing that the Federal Circuit's preoccupation with making factual determinations has prevented it from taking a leadership role in guiding legal rules). Empirical data suggests that the Federal Circuit is particularly unlikely to defer to district court rulings construing patent claims. See Christian Chu, Empirical Analysis of the Federal Circuit's Claim Construction Trends, 16 BERKELEY TECH. L.J. 1045 (2001); Kimberly A. Moore, Are District Court Judges Equipped to Resolve Patent Cases?, 15 HARV. J. L. \& TECH. 1 (2001). Rai also argues that the Federal Circuit has not shown sufficient deference to factfinders in obviousness and disclosure cases. See Rai, Facts, supra note 199.

200. In this respect we agree with Wagner, who argues that improper determinations of the PHOSITA in one case should not bind courts in a later case. Wagner, supra note 125 , at 6 . But since the Federal Circuit has relied on such prior determinations, we see the current state of affairs as more problematic than he does.

201. See Meara, supra note 126 (arguing that the existing factors for determining skill in the art do not work very well, and suggesting ways to refine the PHOSITA inquiry). 
time a patent is filed, rather than as of the date of invention, a larger pool of prior art will frequently be imputed to the knowledge of the enablement PHOSITA. The accumulation of prior art between invention and filing could in theory allow an invention to enjoy both a low threshold of obviousness and a low threshold of disclosure.

One possible approach — though one we ultimately reject — would be to emphasize this differential knowledge in order to eliminate the tight reciprocity of obviousness and enablement. The temporal disparity in the two PHOSITAs might get the courts some way towards that goal. Since the body of prior art grows during the period between invention and the filing of a patent, the corpus of knowledge imputed to the enablement PHOSITA will be somewhat larger than that imputed to the obviousness PHOSITA. Thus, the level of disclosure required to enable one of ordinary skill at the time of filing could well be lower than that required to enable one of ordinary skill at the time the invention was made, because the enablement PHOSITA is expected to know more. Conversely, an invention may well be nonobvious at the time it is made, although it would not be at the time a patent is filed. ${ }^{202}$

This same effect may hold true for the PHOSITA of the written description requirement, albeit to a lesser extent. The written description requirement substantially overlaps with the degree of disclosure required for enablement, but is likely to require something more. Because the unique purpose of the written description requirement is to demonstrate what the inventor had in his possession at the time the patent was filed, courts have been understandably reluctant to assume that details missing from the disclosure could be supplied by the prior art knowledge imputed to the PHOSITA. Thus, the inventor is less able to rely upon the level of knowledge in the prior art to accommodate a more relaxed disclosure requirement for written description. Nonetheless, some courts have suggested that there is

202. This will depend to some extent upon when the invention is considered to be "made" for nonobviousness purposes. If the inventor must rely upon her filing date as the date the invention is made, then the knowledge imputed to the enablement and obviousness PHOSITAs may be coterminous. However, if the date of invention can be related back to an early time of conception, the disparity between the two bodies of prior art may be substantial. 
some flexibility in the written description requirement, ${ }^{203}$ although that has not been the trend in the Federal Circuit biotechnology cases. ${ }^{204}$

The effect of emphasizing the time difference is that patents are both easier to obtain (since the prior art PHOSITA used in the obviousness inquiry knows less) and broader in scope (since the PHOSITA used in the later disclosure inquiry knows more). Such a result is desirable as a policy matter only if there is reason to believe that there is not currently enough patent protection. Our policy analysis suggests, however, that the real problem in both biotechnology and software lies in the number and scope of patents that are issued, not in inadequate protection. For example, application of a low obviousness threshold and a relaxed disclosure requirement would lead to many valid patents with broad scope. In biotechnology, this will only exacerbate the problem of "patent thickets" identified by Carl Shapiro. ${ }^{205}$ Nor will reliance upon the differential in prior art between obviousness and enablement yield the optimal result in the case of computer software. As we have described, the profile of that industry militates in favor of narrower and more sharply defined patents: in other words, toward a higher threshold of disclosure and not as high an obviousness standard. But, in this case, the differential in prior art between the time of invention and the time of filing pushes in exactly the wrong direction, away from a stringent enablement standard. No matter how high the threshold for obviousness may be set, the passage of time between invention and filing will place more knowledge at the disposal of the PHOSITA at the latter event, favoring less disclosure rather than more. This means that even a decoupled PHOSITA standard will not achieve ideal results in both biotechnology-where the disclosure standards may need to be relaxed somewhat — and software — where they need to be tightened.

203. See, e.g., In re Smythe, 480 F.2d 1376, 1384 (C.C.P.A. 1973) (holding that the written description requirement for an embodiment is fulfilled by "description of properties and functions" of an invention if the disclosure would "suggest to a person skilled in the art" the particular embodiment).

204. But see Union Oil Co. v. Atlantic Richfield Co., 208 F.3d 989 (Fed. Cir. 2000) (upholding a jury determination that functional descriptions of gasoline compositions satisfied the written description requirement). To the extent that Union Oil may signal a shift in the Federal Circuit's approach to written description requirements, it is worth noting that Judge Lourie, the author of most of the biotechnology cases, dissented and vigorously criticized the majority for deciding a written description question on an enablement standard. Id. at 1002-05 (Lourie, J., dissenting).

205. Carl Shapiro, Navigating the Patent Thicket: Cross Licensing, Patent Pools, and Standard Setting, in INNOVATION POLICY AND THE ECONOMY (Adam Jaffe et al., eds., Nat'l Bureau of Econ., 2001). 
Consequently, it is inadequate to rely upon the knowledge differential already found in the PHOSITA standard in order to correct the mismatch of policy outcomes and doctrinal analysis. A more promising approach is to decouple the section 103 and section 112 PHOSITA standards altogether, recognizing that the PHOSITA contemplated for purposes of obviousness is simply not the PHOSITA contemplated for purposes of disclosure. Although tight reciprocity of the two standards, mediated by a common PHOSITA construct, makes for an appealing and intellectually elegant doctrinal framework, theoretical esthetics might be required to give way to technological pragmatics. Again, there are precursors latent in the case law that could be developed into such a doctrinal shift; recall that the section 103 PHOSITA has been portrayed by some courts as a bit of an innovator, while the section 112 PHOSITA has not. ${ }^{206}$ Certainly the two constructs are conceived as being engaged in very different inquiries; the first seeking some motivation to compile prior art knowledge into an invention, and the second drawing upon prior art knowledge to supplement an invention disclosure. Thus, arguably it makes sense that the ordinary inventor of section 103 be a very different person-with a different knowledge set-from the ordinary user of section 112. Divorcing the two inquiries could allow each standard the freedom to independently accommodate the incentive needed by a given industry. In particular, this may be a more felicitous approach for software. If the obvious PHOSITA is expected to know more than the enablement PHOSITA, patents will tend to be narrower than they are today. Fewer patents will be nonobvious, and patentees will have to disclose more. On the other hand, it may prove more problematic in biotechnology cases, where optimal policy would permit broader patents than the law currently does.

\section{CONCLUSION}

Patent law is becoming technology-specific. The legal rules applied to biotechnology cases bear less and less resemblance to those applied in software cases. While there may be good policy reasons to treat the two industries differently, the current legal rules are not expressly informed by the economics of the industries, but by an ad hoc combination of judicial anthropology and stare decisis. Not surprisingly, they do not reflect optimal patent policy in either biotechnology or software. Nor do the court opinions reflect a particularly good understanding of the science in either computer software or biotechnology. We have offered some explanations for this phenomenon, along with a specific suggestion-decoupling the

206. See supra notes $150-155$ and accompanying text. 
obviousness and enablement standards. Decoupling will help courts avoid feeling constrained to make industry-specific legal decisions that are inappropriate as a policy matter-setting an obviousness standard that the court believes required by prior disclosure decisions, for example, or vice versa. It will permit the courts to concentrate on the actual skill of the PHOSITA in a given art at a given time for a given purpose.

Clarifying the role of the PHOSITA will help courts avoid making bad decisions because they did not understand the technology in question, or because they felt bound by a prior court's discussion of the level of skill in the art. It will not address the larger policy problems that result from the industry-specific nature of innovation; those policy problems must be addressed elsewhere. ${ }^{207}$ Nevertheless, if we are to optimize patent policy, getting the PHOSITA right is at least a step in the right direction.

207. See Burk \& Lemley, supra note 5. 